Makale Geliș | Received: 16.06.2020.

Makale Kabul | Accepted: 28.06.2020.

DOI: 10.18795/gumusmaviatlas. 753814
Mavi Atlas, 8(2)2020: 362-388

Araştırma Makalesi|Research Article

\author{
Ceyda POLATEL \\ Öğretim Görevlisi|Teaching Assistant \\ Kocaeli Üniversitesi, Yabanc1 Diller Yüksek Okulu, Kocaeli-TÜRKIYYE \\ Kocaeli University, School of Foreign Languages, Kocaeli-TURKEY \\ ORCID: 0000-0002-1443-7188 \\ ceyda.polatel@kocaeli.edu.tr
}

\title{
Tercüme Dergisinde Kadın Kimliğinin İnşası: Bir Yapısöküm Denemesi
}

Öz

Çeviri çalışmalarında post-yapısalcı yaklaşımların odak noktalarından biri çevirinin kültür ve kimlik inşasındaki rolüdür. Bu çalışmada çeviri metinler ışığında Tercüme dergisinin 1940-1946 yılları arasında çıkan sayılarında Erken Cumhuriyet dönemi kadın kimliğine ilişkin olarak üretilen söylemler ve bu söylemlerin dönemin sosyo/kültürel özellikleri içerisinde iktidarın ürettiği söylemsel yapılarla bağlantılı olan noktaları ve kesintiye uğrayan alanları ortaya çıkarılmaya çalışılmıştır. Böyle bir çalışma derginin yapısökümsel okumasını gerektirmiş ve bu nedenle de dergide yer alan çeviri metinlerin satır aralarında kadına dair görünürlük kazanan ifade bütünlükleri hiyerarşik olmayan bir sentez içerisinde ortaya konulmuştur. Bu şekilde derginin farklı bir okuması yapılarak dergiye ilişkin olarak daha önce belirlenen yapının sökülmesi hedeflenmiștir. Yapıyı sökerken çeviri metinlerin kadın konusuna ilișkin söylemler üzerinden öznenin inşasının ortaya çıkarılmasıyla derginin farklı bir düzlemde yeniden konumlandırılmasını sağlayacak bir takım bulguların ortaya konması amaçlanmıştır. Bu süreçte bugüne kadar dergiye ilişkin olarak öne sürülen iddiaların tekrar gözden geçirilmesini sağlayacak boşluklar, kesintiler ve uyumsuz bütünlükler ise derginin tarihsel konum içerisinde aşkın bir belirleyeninin olamayacağını göstermek üzere detaylandırılmıştır. Bu anlamda Tercüme dergisindeki çeviriler yoluyla kadına ilişkin kurulan bilgi alanlarının ve ürettikleri doğrulukların oluşumunun izini sürülmüş, söz konusun dönemin normları ve kuralları üzerinden işleyen bir iktidar alanının varlığ1 ve öznenin inşasına yönelik unsurlar belirlenmeye çalışılmıştır. Çevirilerin satır aralarında izi sürülen ifade gruplarının genel düzeni ve belirli bütünler içinde bir araya gelişinin, bireylerin ne şekilde özneleştirilmek istendiğini göstermesi bakımından işaret ettikleri kavramlar, bütünlüklerine göre sınıflandırılmıştır. Böylece dönemin iktidar ilişkileri üzerinden bireylerin özneye dönüştürülmeleri esnasında kadın kimliğinin hangi sorunsallaştırmalar yoluyla kurulduğunu tespit edebilmek olanaklı hale gelmiştir. Çeviri metinlerin satır aralarında geçen ifadelerde toplumda kadına yönelik algının dönüşümünü tetikleyici ya da Batılı olmayı özendirici bir kaygıdan çok bazı şeylerin değişmezliğinin ya da devamlılı̆̆ın sağlanmasına yardımc1 motiflerle geleneği koruyucu bir algının üretildiği tespit edilmiştir. Bu nedenle seçilen metin tercihlerinin kadınların geleneksel rollerinin devamlılığını korumak noktasında muhafazakâr bir tavrı güçlendirmeye yönelik olduğu gösterilmeye çalışılmıştır.

Anahtar Kelimeler: Çeviri, Tercüme Dergisi, Söylem, Kadın, Kimlik.

\section{Female Identity Construction in Journal Tercüme: A Deconstructive Reading}

\begin{abstract}
One of the main concerns of poststructuralist translation studies is the power of translation on culture and identity construction. This study aims to reveal the discourses on women during the early republican period in journal Tercïme published between 1940 and 1946 and their relations or discontinuities with the discursive structures produced by the government within the socio-cultural characteristics of the period. Such a study required the deconstructive reading of the journal, and therefore, the integrity of the expressions about women within the lines of the translated texts was presented in a non-hierarchical synthesis. In this way, it is aimed to deconstruct the previous structure of the journal and discover some points that would allow the journal to be repositioned on a different level. In this process, the gaps, breaks and incompatible totalities are detailed to show that the journal cannot have a transcendent determinant. In this sense, knowledge fields about women and the truths they produced has been traced through the translations in Tercïme to find out the existence of any power that operates through the norms and the rules of the period and any factors about the construction of the subject. The general order of the groups of statements traced within the translated texts and their accumulation in certain ways and the concepts they referred are classified according to their integrity to show how the individuals are turned into subjects. Thus, it was possible to find through which problematizations the women's identity was established on. It was found that the statements
\end{abstract}


traced through the lines of the translated texts, constitutes a female identity which preserves the traditional patterns ensuring the invariance or continuity of some values rather than a concern that triggers the transformation of the female identity or encourages a Western way of life for women.

Keywords: Translation, Journal Tercüme, Discourse, Woman, Identity.

\section{Giriş}

1980’lerden itibaren özellikle yapısalcılık sonrası postyapısalcıllğa geçiş ile birlikte çeviribilimin yöntemleri ve nesnel bilginin olanakları sorgulanmaya başlanmış ve Derrida, Foucault gibi postyapısalcı düşünürlerin çalışmalarıyla, çeviri ediminin sınırı, dilsel ve metinsel fenomenin çok ötesine taşınmıştır. 80’li yıllarda yaşanan bu önemli paradigma değişimi neticesinde çeviri çalışmalarında kaynak metin ve kültüre dayalı araştırmalardan, erek metin ve kültürün özelliklerini inceleyen araştırmalara geçilmiştir. Çeviride dikkatlerin erek metne çevrilmesi ile birlikte kaynak metnin ne içerdiği, ne söylediği, ne anlama geldiğinden ziyade çeviri metnin hedef kültürde işlevinin ne olacağı ya da ne olduğu tartışılmaya başlanmıştır. Çeviri etkinliğinin ya da çeviri ürünlerin hedef kültürdeki varlık nedeninin sorgulanması, ideoloji, güç dengeleri, toplumsal normlar, söylem gibi kavramların çeviri ile olan ilişkisini gündeme getirmiştir. Bu noktada çeviri etkinliği bir dil, çevirmen, metin ya da çeviri sürecinin ötesinde, sonuçları bir toplumun bütün kesimlerini etkileyen ve dönüştüren bir olgu olarak toplumsal yaşamın merkezinde yer almaya başlamıştır (Arı, 2014: 36). Çeviri faaliyetini, bir dil etkinliğinin ötesinde bir kültürel olgu olarak ele alan kuramlar, çeviride evrensel doğrulardan ziyade toplumsal ve tarihsel farklılıkları dikkate almaya başlamıştır. Bu nedenle postyapısalcı çeviri kuramları, dilin maskelediği hiyerarşiler ya da dışlamalara odaklanarak toplumsal kurumların ve sosyal faaliyetlerin oluşumunda ve işleyişinde çevirinin rolünü irdelemeye odaklanmıştır. Bu aynı zamanda çeviri çalışmalarında detaylı bir kültürel ve siyasi çalışmayı da gerektirmiştir (Venuti, 2000: 336). Bu bağlamda bir kültür etkinliği olarak düşünüldüğünde bir topluma ve döneme ait çeviri etkinliğini incelemek aynı zamanda o dönemin ve toplumun içinde bulunduğu siyasi, sosyal ve kültürel değerlere de 1 şı tutulması anlamına gelir. Çünkü çeviri, çevirisi yapılacak olan eserlerin benimsenmesi ya da dışlanmasında etkili olan güç ilişkileri, ideoloji, iktidar, kurumlar, özneler gibi dinamiklerin etkisi ile şekillenen bir eylem olarak düşünülmeye başlanmıştır. $O$ halde çeviri etkinliği, belirli bir tarihsel dönemde ve toplumsal koşullar altında gerçekleştirilen bir etkinlik olarak ancak söz konusu bu dönem ve koşullarla birlikte çözümlenirse bir bağlama oturtulabilir.

Bu çalışmada Maarif Vekili Hasan Âli Yücel döneminde 1940- 1946 yılları arasında yayımlanan Tercüme dergisi kapsamında yer alan çevirilerin incelenmesi de benzer bir çabanın ürünü olarak ortaya konmuştur. Araştırmanın temel sorunsalı Tercüme dergisine yönelik mevcut çalışmalarda yer alan hâkim kanaatin kadın kimliği üzerinden yeniden değerlendirilmesi ve alternatif bakış açıları ile derginin yeniden kurgulanıp kurgulanamayacağının ortaya çıkarılmasıdır. $\mathrm{Bu}$ açıdan Cumhuriyet Dönemi’ndeki hâkim kadın söylemleri ekseninde, ceviri, kültür, söylem, ideoloji, özne kavramları, Tercüme dergisindeki çeviriler üzerinden tekrar ele alınmıştır. Çevirilerde kadın kimliğine ilişkin söylemleri belirlemek üzere derginin 1940-1946 y1lları arasında çıkan ilk 33 sayısının bir bütün olarak incelemesi yapılmıştır. Bu süreçte ise dergide yer alan çeviriler, yapısöküm ${ }^{1}$ tekniği ile tekrardan okunarak metinlerde kadın kimliğine ilişkin görünürlük kazanan özellikler tespit edilmeye çalışılmış ve bunların Erken Cumhuriyet Dönemi iktidarının söylemlerinde yer alan kadın profili ile hangi ölçekte ne kadar uyumlu olduğu gösterilmiştir.

\footnotetext{
1 Yapısökümsel okuma çift yönlü bir okuma tekniğidir. İlk okuma, metin ve ona ilişkin varsayımlar, kavramlar ve tartışmalar hakkında egemen yorumu takip edebilmek için herhangi bir tesir altında kalmadan yapılmıs tarafsız bir okumadır. İkinci okuma, metinde dile getirilmeyen, baskılanan ya da daha önemsiz farz edilen yorumların izini sürmek ve böylece metinde gizli etkiyi yaratan unsurları açığa çıkarmak için yapılan okumadır. Metne ilişkin egemen yorum ve ona göre daha arka planda kalan yorum ya da yorumlar arasında kurulacak olan metinsel hiyerarşi, egemen yorumun neyi dışladığına bağlı olarak kurulur (Rasiński, 2011: 11).
} 


\section{1. Çeviride Postyapısalcı Yaklaşımlar}

Çeviri alanında 90’lı yıllara kadar öne sürülen betimleyici yaklaşımlar, çeviriye bilimsellik kazandıran önemli kuramlar olmasına rağmen nesnellik uğruna, yorum ve değerlendirmeden uzak bir şekilde var olanı inceleme amacını taşıdığı için postyapısalcı görüş tarafından eleştirilmiştir. Rosemary Arrojo, Lawrence Venuti, Tesajwini Niranjana, Gayatri Spivak gibi düşünürler, çeviribilimin bu nesnellik kaygısını eleştirerek betimleyici araştırmaların özcü ve tek bir gerçekliğin peşinde olduğunu iddia etmişlerdir (Asis Rosa, 2010: 102). Özellikle Derrida'nın yapısöküm kavramı çerçevesinde metnin anlamının sorgulaması ile çeviriye ilişkin olarak sorulan soruların seyri değişmiş ve çeviri metin ile orijinal metin arasındaki belirsizlik, çeviri çalışmalarını farklı bir boyuta taşımıştır. Metnin anlamının ne anlama geldiğinin sorgulanması, anlamın metnin içinde ya da dışında olan bir şey olmadığını, onun ancak yorum yoluyla metne katılabilir bir şey olduğunu gündeme getirmiş ve orijinal metinde mevcut olduğu varsayılan tek bir anlamın söz konusu olamayacağı görüşü ağırlık kazanmaya başlamıştır. Böylece aşkın bir orijinal metin olmadığı gibi eksiksiz ve bütünsel olarak tamamlanmış bir metin ya da çevirinin de mümkün olmayacağı tartışmaları gündeme gelmiş ve çeviri olgusu farklı bir düzlemde tartışılmaya başlanmıştır (Van Wyke, 2010: 113).

Postyapısalcı düşünceye göre bir kaynak dil ya da bir kaynak metindeki kavramlar ve anlamlar keşfedilmez; ancak inşa edilebilir. Bir inşa sürecinde, inşa edilme koşulları hiçbir zaman aynı olamayacağı için hiçbir zaman bir metin başka bir dilde tam olarak yeniden üretilemez. $\mathrm{Bu}$ nedenle kaynak metnin bir çevirisi, birçok farklı anlamı ve metinler arası karşılaşmaları içerir. Dolayısıyla kaynak metin ya da çeviri metin keşfedilebilen ya da kanıtlanabilen, daha önce var olan bir şey değil; inşa edilebilen, kurumsallaştırlmış bir şeydir ve bu nedenle her zaman tekrar revize edilerek değişime uğraması ihtimali mevcuttur (Davis, 2001: 16). Yapısökümcülerin çeviriye ilişkin olarak geliştirdikleri kuramlar, bugüne kadar çeviriye ilişkin olarak sorulan soruları tersine çevirerek orijinal metnin yokluğu üzerinden hareket eder. Bu bağlamda, kaynak metnin çeviriyi var ettiğine dair klasik düşünce biçimini tersine çevirerek, çevirilerin kaynak metni yarattı̆̆ına ilişkin sorular sorar. Tartışmalarda, kaynak metnin varlık sebebi olarak metnin kendi özgün niteliklerinden çok metne dair yapılan çevirilerin nitelikleri gösterilir. Böylece sorulan soruların odak noktasında metnin anlamının, kaynak metnin kendisi tarafindan değil çeviriler tarafından yapılandırıldığı yer alır. Kaynak metnin oluşmasını sağlayan şeyin ardında yatanın bir fikir ya da bir biçim olup olmadığına dair öne sürülen görüsslerden sonra hiçbir şey olmadığına dair düşünceler üretilir. Tüm bu tartışmaları yürüten yapısökümcüler, nihai noktada bizlerin çeviri metni yazdığımızı değil, çevirilerin bizi yazdığını iddia etmeye varan önerileri ile oldukça radikal bir bakış açısıyla çeviri alanına yeni bir perspektif sağlamış olur (Genztler, 2001: 145-146). Foucault, Derrida gibi postyapısalcı düşünürlerin yazı, metin, yazarlık, söylem gibi kavramlara ilişkin olarak geliştirdikleri fikirler, çeviri çalışmaları açısından kaynak metin, çeviri metin, kaynak dil, çeviri dili gibi kavramların birbirinin yerine geçmesini kolaylaştırarak aralarındaki kaynak odaklılık/hedef odaklılık, iyi/kötü, serbest/kuralcı gibi çeviri yaklaşımlarının mantığını sarsmıştır. Tekrardan üretilecek bir aşkın ve orijinal metnin yokluğu, bu çalışmada çeviri metinlerin orijinallerinden bağımsız bir şekilde incelenebilmesine olanak tanımıstır. İncelenen nesneler her ne kadar çeviri metinler olsa da çeviri kavramı, burada orijinal metnin anlamının aktarılmasından ziyade derginin söylemi içinde öznenin yapılandırılmasını sağlayan bir etkinlik olarak ele alınmıştır.

Çeviri çalışmalarında post-yapısalcı yaklaşımların odak noktalarından biri, çevirinin kültür ve kimlik inşasındaki rolüdür. Çevirinin kültür ve kimlik inşasındaki rolü, ulusal ve kültürel kimliklere dair ilkçi/primordialist yaklaşımların geçerliliğinin yıkılması ile de yakından ilişkilidir. Ulusal/kültürel kimliklerin nesnel tarihsel süreçlerin bir ürünü ya da doğal, verili bir gerçeklik olarak değil; hayal edilmiş (Anderson 1991) ya da icat edilmiş (Hobsbawn, Renger 2001) bir oluşum, inşa edilmiş ve sürekli yeniden inşa edilen kategoriler olarak tanımlanması ile birlikte bu inşanın nasıl ve kimler tarafindan gerçekleştirildiği sorulan gündeme gelmiştir. Her disiplin kendi alanı 
açısından bu soruları yanıtlamaya çalışırken, çeviri alanındaki çalışmalar da çevirinin ve çevirmenin kimlik inşasındaki önemine odaklanmıştır. Toury, bu anlamda çevirmenleri ve çevirinin üretim aşamasından tüketim aşamasına kadar uzanan süreçte rol alan tüm kişi, kurum ya da kuruluşları değģsim özneleri (agents of change) olarak adlandırır. Ona göre bu süreçte yer alan tüm özneler, ait oldukları kültürün repertuarını değiştirebilecek yeni alternatifler sunarak kültürü ya da toplumsal kimlikleri yeniden inşa ederler. Toury, bu bağlamda, kültürü, toplumsal ilişkileri düzenleyen inşa edilmiş repertuar (repertoire) ${ }^{2}$ seçenekleri bütünü olarak tanımlar (Toury, 2002: 150-151). Toury, Even-Zohar'in toplumsal ve bireysel yaşamda yeni repertuar seçeneklerinin bilinçli bir şekilde yaratılması (Even-Zohar, 2008: 277) şeklinde tanımladığ1 kültür planlamasını (culture planning) bir inşa süreci olarak ele alır ve çeviri etkinliğini bu inşa sürecinde başvurulan etkin yöntemlerden biri olarak kabul eder.

Çeviride hangi metnin orijinal olarak değerlendirilip değerlendirilemeyeceğine dair yaşanan kaos ve postmodern çeviri kuramlarının öne sürdüğü görüşler, ister istemez çeviri metinlerin orijinal eser gibi düşünülmesini kolaylaştırmıştır. Bunun yanı sıra kimlik, inşa süreci gibi kavramlara dayalı olarak çevirinin kültür planlaması üzerinden ulus inşa sürecinde bir kimlik yaratma aracı olarak görülmesi ve çeviri metinler aracıllğıyla bir ulusun yeni hayatına ilişkin değerler, yaşam biçimleri vb. seçenekler bütününün (repertuar) neler olduğunun araştırılması, çeviri metinlerin söylemsel olarak ne ifade ettiğinin tespit edilmesi anlamina da gelir. Çünkü çeviriler aracılığıyla aktarılan ifadeler aynı zamanda öznenin dilsel olarak kurgulandığı yerler olarak düşünülebilir. Bu çalışmada kaynak metne bakılmadan çevirilerdeki söylemlerin tespit edilmesini de bu düşünce üzerine temellendirilmiştir. Dolayısıyla bu çalışmada, kadın kimliğinin inşası üzerine, çevirilerin kaynaklarından bağımsız bir şekilde incelenmesinde bir sakınca olmayacağını söylemek mümkündür. Çevirilerde görünürlük kazanan kadın söylemlerinin, Tercüme dergisinin üretildiği dönemin sosyo/kültürel özellikleri içinde iktidarın söylemsel yapıları ile bağlantılı olan noktalarını ve kesintiye uğrayan alanlarını tespit etmek üzere yapılacak olan bu çalışma aynı zamanda derginin yapısökümsel okumasını gerekli kılmıştır.

\section{Tercüme Dergisinin Yapısökümü}

Yapısöküm metne dişardan uygulanabilecek herhangi bir okuma, söz söyleme ya da yorumlama yöntemi ve teorisi değildir; ancak metne içerden katılabilir bir süreçtir (Lucy, 2004: 12). Derrida'nın ifade ettiği üzere yapsiöküm bir analiz ya da eleștiri değildir... bir method değildir ya da bir yönteme dönüstürülemez... belirli bir kurallar bütününe indirgenemez... yapısökü̈m olur... kendi kendini yapısöküme uğratır... (Derrida, 1985: 1-5). Derrida, kendi okuma stratejisini şu şekilde tanımlar: Okuma, yazarn dili kullantrken bâkim olduğn ve olmadiğg dil kalıplar arasinda, yaz̧ar tarafindan

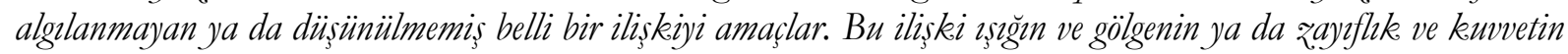
dağılım gibi nicel bir ilişki değildir, eleştirel okumanın üretmesi gereken bir anlamlandırma yapısıdır (Derrida, 1981: xv). Bu, yazarın görmeye gerek duyduğu şeylerle görmedikleri arasında sistematik bir ilişki ortaya koymaktır. Dolayısıyla görünen, açı ve evrensel kabul edilen șeylerin, öyle olduklarna dair gecmişi ve sebepleri olduğunun ve kendinden sonra gelen șeyleri etkilediklerinin gösterilmesi amactyla verili ya da doğal bir olusum olmadıklarmi; kültürel olarak yapılandırldıklarm göstermek amacuyla yapılan elestirel bir analizdir (Derrida, 1981: xv). Yapısökümsel bir okuma şunlar1 varsayar: İddianın retoriği ile iddianın açık anlamı mutlak bir biçimde uyumlu olmayabilir, bu uyumsuzluk sistematik ve anlamle bir şekilde okunabilir, bir nesne analiz edilebilir sapmalar aracilğgyla okunabilir (Derrida, 1981: xvi).

Postmodern söylem teorilerinde, bir metnin yapısökümsel okuma biçimi, edebi metinlerin yaratıcı bir şekilde okunmasını sağlayarak; onların yeniden anlamlandırılmasında ve değerlendirilmesinde kullanılır. Yapısöküm yaklaşımına göre, her okuma, bireysel bir etkinliktir ve

\footnotetext{
${ }^{2}$ Repertuar, bir grup ya da o gruba ait bireyler tarafından hayatın düzenlenmesi için kullanılan seçenekler bütünüdür. bkz. Itamar Even-Zohar (2002), "The Making of Culture Reperoire and the Role of Transfer", Translations: (Re) Shaping of Literature and Culture, der. Saliha Paker, İstanbul: Boğaziçi Üniversitesi Yayınları, s. 166.
} 
bir metinde tek ve mutlak bir anlama hiçbir zaman ulaşılamaz; çünkü her okuyucuya göre metnin algilanış1 yeniden kurgulanabilir ve bu nedenle de metinlerde hiçbir zaman bir başlangıç ve sonun olmadığı düşünülür. Klasik görüşe göre, bir metni okurken okurdan beklenilen, yazarın düşündüklerinin ve anlatmak istediklerinin anlaşılmasıdır. Bu süreçte metnin anlaşılması, metinde var olan ve metinde söylenilenin yorumlanması ile eșdeğerdir. Yapısökücümcü yaklaşım, ise okurken görünmeyeni de söylenmeyeni de sürece dâhil eder. Metinde söylenmeyenlerin de düşünülmeye başlanmasıyla birlikte okumanın alanı genişler ve hatta bu alan okuyucu tarafindan sınırsızlaştırılabilir. İşte bu nedenden ötürü yapısökümcülükte okur pasif bir durumdan aktif bir duruma geçer (Eroğlu, 2012: 1095-1098).

Adını destrïksiyon ve konstrükesiyon kavramlarından alan dekonstrüksiyon (yapıs̈̈küm) kavramı, bu sözcüklerin anlamına bakıldığında hem bozmak (yıkmak) hem de yapmak (kurmak) anlamlarını içerir. Bu nedenle yapısöküm sürecinde amaç, sadece bozmak ya da yok etmek değil; yapıları parçalarına ayırıp tekrardan birleştirmektir. Bu aslında metin içerisindeki hareketli parçaları, başka düşünceler üzerine yeniden inşa etmek anlamına da gelir. Buna göre de metinlerde bir başlangıç ve son kavramından söz etmek yersiz olacaktır (Saydam, 2009: 159-171). Kendine özgü mantık merkezi olan sağlam bir yapıya sahip ve kendine ait dönüşüm kuralları olan bir sistemin yapısını bozmak, onun mantık merkezini alt üst etmek anlamına geleceği gibi onu yeniden yapılandırmak ise bu mantık merkezinin yerine yeni bir mantık merkezi yerleştirmek demektir. Derrida'ya göre herhangi bir sosyal, kültürel ya da metinsel sistem, kendi mantık merkezi etrafinda bu mantık merkezini destekleyici birbirine benzer unsurların bir araya gelmesiyle ve ön plana çıkmasiyla ortaya çıkar. Sistem içerisindeki farklı unsurlar aslında en dinamik sayılabilecek unsurlardır ancak sistem içerisinde görmezden gelinerek bastırllır veya yok sayılır (Moran, 2011: 83).

Tercüme dergisi bugüne kadarki yapılan çalışmalarda ağırlıklı olarak hümanist kültürün bir taşıyıcısı biçiminde ve Türk Rönesansı' inı gerçekleştirmek için araçsallaştırılan çeviri hareketinin bir uzantısı olarak ele alınmıştır. Bu noktada derginin yapısının temel belirleyeni olarak bümanizmi ve onunla ilişkilendirilen Türk Rönesansı ve dönemin söylemini belirleyen akıl, ilerleme, bilim, medeniyet, antik Yunan, Rönesans gibi değerleri göstermek yerinde olur. Yapılan çalışmalarda derginin kendi sisteminin dışında çevirmen, yazar, yayın dönemi, önsöz, yayın politikaları gibi başka unsurlara gönderme yapılarak incelenmesi, onları yapısalcı yaklaşımlardan kısmen uzaklaştırmış gibi görünse de dergideki somut ve tek tek unsurların ardında aşkın bir belirleyenin gösterilmeye çalışılması onları yine tam da yapısalcılığın merkezine yerleştirir. Bu çalışma ise Tercüme dergisinin yapısı içerisinde yer alan dinamik unsurlar arasından kadın kimliğine ilişkin referansları bulup açı̆̆a çıkarmayı ve bu esnada hem birbirine benzeyen hem de farklı olan bütün unsurlardan oluşan hiyerarşik olmayan bir sentezi yakalayabilmeyi hedeflemektedir. Süreç esnasında çeviri metinlerin söylemsel olarak ifade ettiği düzlemleri tespit edebilmek için çeviri metinlerin satır aralarında kadın kimliğine ilişkin görünürlük kazanan ifadeleri belirlemek ve bu ifadeler üzerinden öznenin ve kimliğin inşasını oluşturmaya yarayan değerleri ortaya koymak gerekmiştir. Ancak öncelikli olarak dönemin kadın algısına ilişkin söylemlerin ve modernleşme sürecinde kadın kimliğine yüklenen anlamların neler olduğuna kısaca değinilmesi yukarıda bahsedilen sentezin oluşturulması açısından önem arz etmektedir.

\section{Türk Modernleşmesinin Seyrinde Kadın}

Kadınlar genellikle milletin ve modernliğin temsillerinin merkezinde yer alır. Ancak seçkinler, ulus-inşa sürecinde ulusu, kendi çıkarlarını ileriye taşıyabilecek şekilde inşa ederken bu ulusal projede kimlerin marjinal kimlerin merkez rolleri alacağını da belirler ve bu inşa süreci genellikle erkeklik ve heteroseksüelliğe dayalı bir ablaki kod ile kurulur. Bu nedenle de iktidar sahipleri, ulusal ideallerinde kadını daha geleneksel ve ahlaki kodlarla disipline edecek bir söylem kullanırlar (Mayer, 2000: 12). Ulusun sınırlarının belirlenmesi, ulusa dâhil olma ve kurucu mitlerin oluşturulması bağlamında ulusun farklı birçok anlamı olabileceği ve bu anlamların kadınlık ve 
erkeklik kavramları üzerinden ne şekilde oluşturulabileceğine dair araştırmalar, kadınlar üzerinden ulusal karakterlerin belirlenimine dikkat çekmektedir (Ranchod-Nilsson \& Tétreault, 2000: 4). Ancak Ahıska'nın da belirttiği üzere kadınlar hem Batı'da hem de Batı'nın dışındaki modernleşme süreçlerinde, millilik vurgusundaki merkezi konumlarının aksine aktif birer özne olmaları anlamında ikincil kılınmıştır. Bu yönelim bir yandan kadınlar için sürekli vurgulanan modernliğin aynası konumu ile öte yandan kadınların marjinalleştirilen deneyimleri arasındaki uçurumu gizlemek adına, kadınlara özgü çeşitli kadınlık mitlerinin oluşturulmasına neden olmuştur. Bu mitlerin temel dinamikleri, toplumsal düzenin devamlllı̆̆ için modernleşme/uluslaşma süreçlerinde kadın cinselliğinin denetimi ve medeniyetin kötü yanlarına karşı panzehir olarak kadınlara tarih dışı doğal bir iyileştirme gücünün atfedilmesi olarak belirginleşir (Ahıska, 2005: 278).

Aynı şekilde Türkiye'nin modernleşme/uluslaşma sürecine bakılacak olursa benzer bir metodun takip edildiğini görmek mümkündür. Erken Cumhuriyet dönemi seçkinlerinin ulusdevlet inşasında kadınlar, siyasal reform süreçlerinde kurucu erkeklerle eşit statüde devlet yönetimine katılan ve toplumsal firsatlardan faydalanan vatandaşlar olmak yerine ulusun anaları, geleneğin ve milli kültürün taşıyıcıları olarak yer almışlar ve erkeklerden farklı toplumsal alanlarda kamusallaşma hürriyetine sahip olabilmişlerdir. Dolayısıyla kadın kimliği modernleşme sürecinde eşit vatandaşl1k statüsünden çok, Türk milli ve modern kimliğini dünyaya gösteren ve kültürel farklıların sınırını temsil eden bir kültür simgesi olmakla anlam kazanmıştır (Sancar, 2017: 112). Tanzimat Dönemi'nden Cumhuriyet'e kadar uzanan modernleşme/uluslaşma süreçlerinde dönemin aydınlarınca geliştirilen formülasyonlar, özellikle düzenli bir değişimi öngören uluslaşma ve batının tehdidine karşı bağımsızlık idealleri ile şekillenirken, kadın, Türk kimliğinin modernleştirici yüzü ve aynı zamanda Batı'ya karşı sınırını çizdiği alanlardan biri olmuştur. Tercüme dergisindeki kadın temasına ilişkin olarak görünürlük kazanan ifadeleri bu bağlamda anlamlandırabilmek için Tanzimat Dönemi'nden itibaren kadına ilişkin olarak ortaya atılan görüşlere kısaca değinmek gerekir.

Osmanlı İmparatorluğu çöküş sürecindeyken bu devlet nasıl kurtarlabilir sorusuna yanıt arayan İslamcılık, Türkçülük ve Batıcılık (Tunaya, 2016: 67) akımları içinde yer alan tartışmaların üçü de ilerlemeci ve Batı merkezli reformdan yana olmalarına rağmen kültürel kimlikler konusunda önemli görüş ayrılıklarına sahiptir. Bu görüş ayrllıkları kimlik ve medeniyetin hangi referanslara göre belirleneceği konusunda ortaya çıkarken kadın kimliğinin kurgulanacağ1 değerlere ilişkin olarak günümüze kadar uzanan tartışmaların da seyrini belirlemiştir.(Göle, 1996: 36). Bu tartışmalar içerisinde modernleşmenin ancak Batılılaşma ile mümkün olacağını savunan Tevfik Fikret, Selahattin Asım, Abdullah Cevdet gibi batıcılara göre, İslam'ın öngördügü kültürel yapılanmalar, ilerlemeci hedef önünde bir engel oluşturur. Bu gibi düşünürlere göre kadınların geri kalmasının nedeni dinin kadınlar üzerindeki denetim ve baskılarıdır (Göle, 1996: 37-39). Bu görüşü savunan aydınlara göre kadınların dinsel yasalara uygun bir şekilde sadece zevce ve çocuk anası olarak yaşaması ve böylece toplumsal alandan dişlanarak toplumsal işlevlerinden koparılması, kadının insan gibi değil şehvet ve üremeye hizmet eden bir araç olarak görülmesine neden olmuştur. Medeni bir toplum yaratabilmek, kadın ve erkeğin eşit derecede özgür bireyler olarak toplumda yer alması ile mümkün olacağı için kadının insanllk mertebesine eriştirilmesi, kadının eğitilmesi ve İslami geleneklerden sıyrılması temalarını gündeme getirmiştir (Göle, 1996: 37-40). Buna karşılık İslamcı akım, batılı idari ve teknolojik yeniliklerin uygulanmasını ilerleme stratejisi olarak kabul ederken Osmanlı'nın kendine özgü toplumsal kültürel yaşamını, kadının ahlaki değerleri ile özdeşleştirerek tanımlamıştır. Bu bağlamda kadın hakları konusunda özgürleşme girişimlerinin topluma zarar vereceğini; Batılı kadın modelinin benimsenmesinin toplumda yozlaşmaya yol açacağını öne sürmüştür. İslamcılar, bunu Avrupa taklitçiliği olarak değerlendirmiş ve kadının yaşam alanını ev ile sınırlamışlardır. İslamcı düşünürlerden sayılan Mehmet Akif (Ersoy) yazdığ1 şiirlerde Batıcılığa karşı çıkmış ve Batıcıllğın kadınların örtüsünü, 
iffetini yok ettiğini dile getirmiştir (Sancar, 2017: 91). İslamc1 akımın düşünürlerine göre İslamiyet taassup ve hurafelerden arındırıldığında, Müslüman bir kadının, ihtiyacı olan tüm hak ve özgürlükleri kendi bünyesinde barındırdığı anlaşılacağı için aile ve kadınlık bahsinde Batı medeniyetine öykünmeye gerek kalmayacaktır (Ülker, 2016: 51). Nitekim İslamcılar, Batı'nın ablaki bubranna karșı toplumun korunması görüșünde birleșerek, Batı etkisini kadınların İslami terbiyeye ters düşmesi olarak algılamışlardır. Bu nedenle Batının etkisiyle Türk kadının ahlakındaki bozulma cemiyet hayatının yozlaşması ile eşanlamlı kullanılmıştır (Göle, 1996: 43). Türkçülük akımının önderleri, kadının sosyal konumunun iyileştirilmesi ve toplumun Türklükle bağdaşmayan geleneklerinden ayrıştırılması için toplumun ıslahını zorunlu görmüşlerdir. Bu bağlamda Türkçü akımın en önemli ideoloğu Ziya Gökalp, çağdaşlaşma sürecinde siyasal ve toplumsal yap1 içerisinde yeni Türk kadın kimliğinin oluşturulmasında kadın imgesini özellikle yeni bir ablak anlayışzyla ele almıştır. Ancak bu yeni ahlak anlayışı, Batı kültürüne has bir ahlak anlayışı değil, İslam öncesi Türk kültürünün kendine has unsurlarında mevcut olan toplumsal ahlak ile kavramsallaştırılan bir ahlak anlayışıdır (Şimşir, 2007: 37). Türkçü aydınlar üzerinde, Ziya Gökalp kadar etkili olan Ahmet Ağaoğlu, Mehmet Emin, Hamdullah Suphi, Yusuf Akçura, Halide Edip gibi düşünürler de kadın hakları konusunda geçmişte yaşamış Türk toplulukları üzerinden bir alg1 yaratmışlardır. Türkçülere göre Türk toplumlarında kadınla erkek her zaman yükü birlikte üstlenmişler ve kadınlar toplum içinde erkeklerle eşit haklara sahip olmuşlardır. Kadınlar ve erkekler birlikte devlet ve memleket işlerini yönetmişlerdir. Bu nedenle Türkçülere göre vatan ve memleket işlerinde kadın ve erkeklerin her zaman yan yana olabilmesi gerekir. (Sancar, 2017: 91) Bu bağlamda yeni kadın imgesi, Batılı kadın tahayyülünden farklı bir boyutta tanımlanmış ve Türkçü-milliyetçi bir perspektifte İslamiyet öncesi Türk eşitçiliğinin taşıyıcısı motifi ile biçimlendirilmiştir.

Erken Cumhuriyet Dönemi ulus-devletinin erkek seçkinleri de kadınlık metaforundan, hem modernleşme amacı açısından hem de millî birlik ve düzenin istikrarının sağlanması açısından simgesel bir öğe olarak yararlanmışlardır. Kadınlar bu süreçte hem cemaat merkezli (geleneksel), hem de devlet merkezli (modern) politikaların nesneleri durumunda bir yandan geleneğin devamı öte yandan gelenekten kopuşun göstereni olarak bu süreçteki yerlerini almışlardır (Berktay, 2012: 277). Vatanı bir kadın bedeni olarak temsil eden bu söylemde, erkeklerin birliğini ve dayanışmasını temel alan bir ulusal kimlik inşa edilmiştir. Bununla birlikte eski statü toplumundan yeni sözleşme toplumuna geçişin bir ifadesi olan ulus-devlet projesinde, kadınlara atfedilen geleneksel roller de modern biçimler altında devam etmiştir. Bu noktada kadınlar için doğru olan davranış kalıplarını belirleyenin din ya da gelenek değil, ulus- devletin olduğunu dile getiren Berktay, ulus- devletin bu bağlamda kadınların hayatını düzenlemek üzere belirlenen politikaların, devlete bağlllı̆̆ın ve resmi ideolojinin önemli bir bileşeni olduğunu söyler (Berktay, 2012: 278). Sancar'a göre Erken Cumhuriyet Dönemi reformcu erkeklerin kadını modernleşme sürecindeki toplumsal projelere dâhil etme girişimlerinde, kadınları hem toplumsal değişimin güvencesi; hem de kültürün taşıyıcısı ve geleneğin devamı olarak görmeleri kadınlara ilişkin kurulan bu denklemin ifadesini ve çözümü oldukça güçleştirir. Dönemin bakış açısına göre geleneğin devamlılığında kadınlar hem iffet ve faziletlerini koruyacak hem de kamusal alana çıkmanın getirebileceği toplumsal yozlaşmaları önleyecek bir görevle yükümlü kılınarak bir önceki dönemin kadınlara ilişkin ortak kanaatinin devam ettirilmesinin nesnesi olmuşlardır (Sancar, 2017: 107).

Cumhuriyetçi modernleşme projesinin sözcüsü ve Tek Parti yönetiminin en büyük destekçilerinden, CHF'nin yayın organı Hâkimiyet-i Milliye'nin başyazarı ve Ulus gazetesinin yazarı Falih Rıfkı (Atay) (1894-1971)'in kadınlar hakkındaki görüşleri, kurucu kadrolar içindeki önemine bağlı olarak dönemin kadın kimliğinin oluşturulmasına ilişkin bir fikir verebilecek niteliktedir:

Kadının başlıca işi evidir. Evden artabilen kadındır ki dışarı işini arayabilir. Bir aile için kazanan erkekten, öteki ev mekanizmasını ev kazancına uyduran kadından mürekkep aile: 
ilk isteğimiz budur... Her müessese gibi aile ocağının da manevi ve maddi iki esas unsuru vardır: ahlak ve teknik! Ahlak bütün ailenin malı, teknik bilhassa kadının malıdır. Ahlak ve teknik evin manevi havası, maddi rahatı ve güzelliği demektir... Tanzimat'in bütün kusurları gibi, iktisadi ve ticari kusurları gibi, içtimai kusurunu da yeni Türk düzeltiyor. Yeni Türk'ün yaptığ1 Türk evini ve kadınını Asyalılı̆̆a doğru, bulvar Avrupası'na doğru değil, mahalle Avrupası'na, sahne Avrupası'na değil, hom³ Avrupası'na doğru ilerletiştir. Çünkü Tanzimat Osmanlısıyla yeni Türkün farkı, birinin garp maymunluğu yerine ötekinin tam garplılığı ikame etmiş olmasıdır...(İsmet Paşa Kız Enstitüsü hakkında) Türk evine zevk ve teknik sokarak ona hom rahat ve güzelliği vermekle kalmayacak, Türk evine tasarruf sokacaktır... Türk evi tasarrufa muhtaçtır, yani kadın bilgisine muhtaçtır... Milli politika Türk milletini Avrupa haraç güzarlığından kurtarmaya çalıştığ1 gibi, aile politikası da Türk evini çarşı haraç güzerlığından kurtaracaktır (Sancar, 2017: 117).

Atay (1932)'ın bu ifadelerinde kadınlara toplumsal görevler yüklenirken iç politikada ulusun bütünlüğünü sağlama; dış politikada da Batı'dan farklı olma hatta Batı'ya üstünlük sağlama ideali temelinde kadınların araçsallaştırıldığı söylenebilir.

Erken modernleşme döneminin kurucu iradesinin şekillenmesinde edebiyat alanında verilen ürünler de dönemin kadın algısı üzerinde etkili olmuştur. Yazarlar, edebi metinler aracılı̆̆ıly diğerlerinin zihinlerine ulaşarak o kafalardaki arzularla iletişim kurmuş ve ortak ya da çatışan imgeler vasıtasıyla tartışmalara ve hayata şekil vermede yönlendirici olmuşlardır (Sancar, 2017: 83). Türk modernleşmesinin kanonik metinlerinin en temelde Batı ile özdeşleşme ve Batı'dan farklı olma arasındaki çelişki içinde şekillendiği görülür. Bu bağlamda Türk modernleşmesinin temel dayanağı olan milliyetçi düşünce, Batıcılık akımlarının etkisinde kalsa da kendini tanımlamada milli kültürünü koruyarak Batı ile sınırlarını belirlemiştir. Kadınlar bu sınırların belirlenmesinin temel dayanaklarından biri olmuştur ve bunu dönemin Türk edebiyatında da gözlemlemek mümkündür. Cumhuriyet Dönemi’nin erkek yazarları, kadını başkaları için var olan, fedakâr ve tamamlayıcı bir unsur olarak görmüştür. Bu görüş, kadınların Türk erkeklere sadakatini millî davaya bağlllıkla eşdeğer gören millîci edebiyatın da bir özelliğidir (Berktay, 2012: 279). Modern Türk kadını sade, ciddi, Batıcı değerlerden uzak, cinselliği belirsiz, bireysel aşk yerine milli ideallere bağlı kadın olarak tasvir edilmiş ve doğallık, namus gelenek, maneviyat, ulus gibi değerler üzerinden tanımlanmıştır (Sancar, 2017: 138).

Erken modernleşme dönemi romanlarında en temel ideolojik yapı, kurucu seçkinlerin arzusunda ortaya çıkan yeni kadını şekillendirme stratejileridir. Bu bağlamda yeni kadina takip etmemesi gereken yollar, yanlış rotalar ve öykünmemesi gereken yaşam biçimleri, romanlardaki kişi ve olay örüntüleri üzerinden tasvir edilmiştir. Bu tasvirlerde esas olarak topluma karşı görevler anlatılırken kadın ve erkek ilişkisinde geçerli olması gereken cinsel ahlaka ilişkin ilke ve öğretiler de mevcuttur. Batıcı değerlere düşkünlük kadınlar için ahlaksızlı̆̆a yol açan kapıdır. Batıcı değerler kadınları madde, çıkar ve para peşinde koşturarak iffetsiz yapar. Oysa doğru kadın mazbut, namuslu ve üretken kadındır (Sancar, 2017: 129-130). Bu bağlamda modern kadın, batılılaşmanın getirdiği aşırılıklara karşı fedakârlık, ailesine bağlılık gibi geleneksel kadın rolleri ile ehlileştirilmeye çalışılırken, geleneksel kadına karşıt olarak da toplumsal alanda eğitimli, irade sahibi, akıllı ve haklarını bilen yurttaşlar olmaları yönünde birtakım siyasi ve toplumsal haklarla donatılmıştır.

Kadınları toplumun biyolojik ve kültürel yeniden üreticileri olarak geleneğin devamı biçiminde ele alan Erken Cumhuriyet Dönemi reformcu erkeklerinin korkularını, arzularını ve kadınlara koymak istedikleri sınırları Yakup Kadri’de bulmak mümkündür. Medeniyetin kadınlara vazifelerini unutturması, Türk hanımlarının geri kalmışlık kaygısıyla dışarı çıkıp başka milletlerin kadınlarına özenip de kendisi olmayı unutmaları gibi endişeler Yakup Kadri’nin yazılarında görünürlük kazanır:

\footnotetext{
${ }^{3}$ Hom, İngilizce ev veya hane karşılığında kullanılmaktadır.
} 
Onlar bu kalabalıkla beraber meçhul bir ufka doğru koşmak istiyorlar ve unutuyorlar ki asıl vazifeleri kalmaktır ve daima ileri doğru koşanları, çok koşarak hududu aşmaktan ve mühlik bir macerada kaybolmaktan men etmektir. Daima her gidenin kalbinde geriye dönem iştiyakı bulunsun diye, geride muhakkak kadının beklemesi lazımdır... Kadınlar milletin usaresi olan ananeleri yegâne muhafızı ve medeniyetin beşiği olan evlerin yegâne nigehbanıdirlar (Sancar, 2017: 115).

Hızlı ve derin toplumsal değişimin neticesinde erkeklerin duyduğu korku duyguları ve tehdit alg1sı sonucunda kadına yönelen ve bu kaygıları onun üzerinden atmaya çalışanlardan biri de Peyami Safa'dır. Ona göre bu sarsıntının en temel sebebi değişen, özgürleşen ve böylece doğal rollerini inkâr eden yeni kadınlardır. Sözde Kıそlar romanında aşırı Batılılaşma ve alafranga düşkünü olan kadın tipi Tango diye adlandırılarak kötü kadın şeklinde kodlanır. Peyami Safa’nın, uğursuz yeni kadına karşı alternatif olarak sunduğu iyi kadm doğaya meydan okumayıp fedakâr, aile bağlarına bağlı, sadık kadındır (Berktay, 2012: 282-283). Halide Edip Adıvar'ın romanlarında kadın kahramanlar akıllı, bilgili, namus ve iffetine düşkün, dini inançları olan, milli ahlak ve kültüre bağlı kadınlardır. Halide Edip'te ideal kadın Atessten Gömlek romanında olduğu gibi vatanı uğruna aşkını, canını verebilen ve ancak aseksüel, bireysel arzu ve isteklerini ikinci plana iten, sade, ciddi, cinselliği belirsiz, milli ideallere bağlı kadındır (Adak, 2011: 163-168).

Toparlamak gerekirse, Türkiye tarihinde kadın üzerine söylemin dönüşümü ve çeşitlenmesindeki yol ayrımının, İslam dinine dayalı teokratik ve çok etnikli bir imparatorluktan laik bir ulus-devlete geçiş ile karakterize olduğu söylenebilir. İkinci Meşrutiyet Dönemi ile ilk ifadelerini bulan kadına yönelik özgürlükçü talepler, İ́lamcı, Batıcı ve Türkçü akımlar bağlamında sancılı bir kültürel arayış ve kimlik bilinci oluşturma kaygılarının ürünü olarak ortaya çıkmışır. Kandiyoti'ye göre İslamiyet'e uygun kadın davranışları ve kültürel bozulmamışlık arasındaki zorlayıcı bağ, ahlaken meşru bileşenler bulmayı oldukça zorlaştırmış ve sorunlu hale getirmiştir (Kandiyoti, 2015: 148). Bu sorunlar da ulusalcı özgürleşme ve Batıc yozlaşmanın getirdiği hararetli tartışmalara konu olan sentezler doğurmuştur. Cumhuriyet Dönemi’nin Türkçülük akımından devraldığı, kadınların özgürleşmesinin Batı'dan ithal bir şey olmadığ1, kökleri Orta Asya'da bulunan Türk kültürüne özgü nitelikler olduğuna dair iddialar, İslamiyet öncesi Türk eşitçiliği vurgusu, kadınlar için yeni bir söylemin oluşumuna kapı aralamıştır. Ancak Kandiyoti'nin de vurguladığ1 üzere, görünürdeki bu değişime rağmen, kadınların konum ve davranışlarını cemaatin hakiki kimliği ile uyumlu ve onu tehdit etmeyecek biçimde milliyetçi ve İslami söylemleri birleştirerek süreklilik içinde devam etmiştir (Kandiyoti, 2015: 147).

\section{Tercüme Dergisi Çevirilerinde Kadın}

Kadın konusuna dair çeşitli öğelerin, Erken Cumhuriyet Dönemi iktidarlarının yaratmak istedikleri toplumsal cinsiyet algısını meşrulaştırmak ve desteklemek için geliştirdikleri söylemler etrafinda biçimlendiği söylenebilir. Kadın kimliğinin bu süreçte nasıl oluşturulduğuna dair ipucu veren toplumsal pratik ve söylemlerin, Tercüme dergisinde çeviriler aracıllğıyla yeniden üretilip üretilmediğinin tespit edilebilmesi, derginin kadın söyleminin, mevcut iktidarın ideolojisi ile uyumlu olup olmadığını gösterecektir.

\subsection{Kadınlarda Diş Güzellik/Huy Güzelliği}

Tercüme dergisinde yer alan çeviriler aracilığıla aktarılan söylemde, kadın teması, Erken Cumhuriyet'in seçkinlerinin görüşlerindeki kadına ilişkin karmaşı ve çelişkili kurgunun bir yansıması olarak değerlendirilebilir. Bu bağlamda dergide çevirisine yer verilen metinlerin, okuyucunun zihninde, kadınlara ilişkin çelişkili bir algının yaratılmasına neden olabilecek unsurlar içerdiği söylenebilir. Çeviri için tercih edilen metinlerin ya da metinlerden verilen kesitlerin, derginin kendi mantığı içinde açıklayamadığı ya da anlamlandırmada güçlük yaşadığı noktalarda, erken dönem modernleşme sürecindeki kadın alg1ları ve kadınlara dair reform projelerine bakmak çevirilerin anlamsal dizgesini sağlayan bir resim ortaya çıkarılmasında yardımcı olmuştur. 
Dergide kadınlarda olması beklenilen özelliklerin temsil edildiği çeviri metinlerden biri, Tercüme dergisinin 4. cildinin 23. sayssinda Cleanthe'nin Hikayesi ismiyle Joseph Addison'a ait bir yazıdır (Addison, 1944: 308-313). Addison, bu yazısında hikâyelerde geçen çeşitli kadın karakterler üzerinden okuyucunun zihninde bir kadında hangi özelliklerin bulunması gerektiğini, hangilerinin olumlu hangilerinin olumsuz özellikler olarak nitelendirilebileceği ile ilgili bir harita çizer. $\mathrm{Bu}$ noktada yazısının ana teması iki farklı kadın tipine ait olumlanan ve olumsuzlanan özelliklerdir. Metnin ana kurgusu, kadınların zenginliğe ve gösterişe olan düşkünlükleri ve bu düşkünlüklerinin başlarına bir takım felaketler getirebileceği üzerinedir. İlgili satırlarda, sıradan kadınların görünüşe çabuk aldandığı ve onları bu konuda besleyen en önemli faktörün de günlük konuşmalar olduğu aktarılır. Bu tür kadınların sohbetlerinin keymetli taşlarla süslü bir farbala, pirlanta dügmeli bir șapka, işlemeli bir yelek veya eteklik üzerine olduğu vurgulanır. Bu kadınlar, sadece dış görünüşlerini düşünür ve insanı faydalı kilan akıl ve zekâa süslerine hiç önem vermezler. Tahsili düşük olan kadınlar için bir kelime ile, dantelâ ile kordele, gümüs ve altın sirmalar ve bunlara benzeyen her türlü manasız şeyler bir yem olarak ifade edilmiştir. Metnin devam eden satırlarında, okuyucu, gerçek mutluluğun kaynağı olarak kendine dönmesi ve bu sayede içsel huzura ermesi yönünde telkin edilir. Mutluluğa dair ilmiklenen bu örüntüden sonra kadın algısına tekrar dönülerek gerçek saadeti taşıyan bir kadında olması gereken özellikler bir kadın karakter örneği ile somutlaştırılır. Gerçek mutluluk kurgusu aşağıdaki betimleme ile tasvir edilir:

Gerçek saadetin çekingen bir tabiatı vardır, debdebeye, gürültüye düşmandır. O önce insanın kendi kendisinden zevk almasından, sonra dostluktan ve birkaç seçkin arkadaş sohbetinden haz duymasından doğar. Gerçek saadet gölgeyi, sessizliği sever, bunun için ağaçlıklarla pınar başlarında, tarlalarla çayırlarda gezer: lâfın kısası her istediğini kendisinde bulur, dinleyici veya seyirci çokluğu ona hiçbir şey kazandırmaz. Aksine olarak yapma saadet, kalabalığı, bütün dünyanın gözünü üzerine çekmeyi sever... başkalarında uyandırdığı takdir hislerinden hoşlanır...(Addison 1944: 311).

Metinde tasvir edilen iki kadın karakterden biri Aurelia'dır. Aurelia, kibar bir kadındır ve köy hayatının sakinliğini sever. Onun en samimi dostu kocasıdır. Birbirilerine âşıktırlar ve ikisi de faziletli ve anlayışlı insanlardır. Birbirilerini sayarlar. Aile hayatları, dua, yemek, çalışma ve eğlence saatleri oldukça muntazamdır. Kalabalık yerlere genellikle sonrasında birbirlerine arzu ile kavuşmak için giderler. Saadeti birbirlerinde bulurlar. Tekrar köye özlemle dönmek için şehre giderler. Onları tanıyan herkes onlara gıpta ile bakar. Diğer kadın karakter olan Fulvia ise kocasına tamamen uşak gözüyle bakar. Ev hanımlığını ve tedbirli olmayı, asil bir kadına yakışmayacak adi vasıflar olarak görür. Aile kurumu, onun için hayatını ziyan ettiği bir yerdir. Tiyatro ya da başka bir eğlencede olmadığında kendini dünyadan ayrılmış gibi görür. Kendi cinsine ait en değerli özellikleri küçümser, kendi halinde ihtiyatlı ve mütevazı bir hayat süren her kadını ruhsuz ve kaba bulur. Fulvia'nın hikâye içindeki tasviri, insanların onun hakkında ne kadar nefret duyduklarının hatırlatılması ile biter.

Yukarıdaki kurgu üzerinden, okuyucuya, kadın karakterine ilişkin olarak verilen iki ayrı model ve bu modelleri temsil ettiği iki ayrı hayat şekli sunulur. Ailesine bağh olmak, sade bir hayat sürmek, kibar olmak ve köy hayatınm sakinliğini içinde barnndırmak gibi daha pasif bir izlenim uyandıran özellikler, kadını daha çekici kılması ile özdeşleştirilerek, okuyucunun zihninde olumlanmıştır. Yazının sonunda kendinden nefret edilmesi ile bağlantılandırılan, daha modern bir hayat tarzı ile aile hayatına bağlı olmayan, ev kadınlığından uzak, kendi aile hayatı dışında farklı toplumsal çevre ve ortamlarda bulunan kadın tipi ise olumsuzlanmıştır.

$\mathrm{Bu}$ çevirinin hemen ardından, yine aynı sayıda Kadın Gürelliğ ismi ile kadın algisının yaratılmasında etkili olabilecek içerikte bir çeviri daha yayımlanır (Steele, 1944: 314-321). Benzer şekilde bu çeviri metinde de iki kadın karakterine ilişkin olarak yapılan tasvir üzerinden kadınlarda olması gereken nitelikler hakkında okuyucuya bazı mesajlar iletilir. Bu iletilerin ana temas1 kadınlarda dış güzellikten ziyade iç güzelliğin önemidir. Makyaj, boyanma, piyasadaki sabte güzellik 
malžemeleri ve kaçak güzellike ilâclar gibi bir takım yöntemlerle kendilerini güzel kılmaya çalışan kadınlar arasında, güzel görünmek, en büyük maharettir. Kadınlar, kendilerini beğendirmek adına bu tür piyasa yöntemlerinin ekmeğine yağ sürmektedirler. Metinde tasvir edilen kadın tiplerinden biri dış görünüş olarak çok güzel olduğu için kendisini topluluk içerisinde kabul ettirme kaygısı olmadan cazibesi ile iş görmüş Laetitia isimli bir kadındır. Kardeşi ise bir o kadar gösterişsiz ve silik bir yapıdadır. Ancak zamanla Laetitia güzelliğinin ona verdiği cazibe ve küstahlıkla sevimsiz, ukala ve itici bir kişiliğe dönüşürken kardeşi Daphne ise kendini topluluk içerisinde kabul ettirmek için bu cazibenin yerini tutacak meziyetler geliştirir. Zaman geçtikçe Daphne çevresine 1ş1k saçan, enerji veren ve insanı huzura kavussturan bir karaktere dönüşürken Laetitia tatsız, anlamsız, soğuk ve kasvetli bir enerjiye sahip bir kadına dönüşür. İlgili satırlarda, bu dönüşüm, okuyucuya, şu cümleler ile kıssadan hisse tadında aktarılır: ..Şabsi kusurlarmı z için kendimiz̨i hor görmek nasıl boș bir kafann harc ise, meziyetlerimiz için kendimizi dev aynasinda görmek de öllece insana yakısmayan bir baldir. Kadinlar bu bususta ıslab edilemeyecek kadar yollarm sapıtmıslardır (Steele, 1944: 317).

Kadınların yalnız yüz güzelliği ile güzel olamayacağı gibi yalnız konuşmak ile de ince zekâlı sayılamayacağını dile getiren satırlarda, gurur kadınların zarafetini yıkan; yapmacık tavırlar ise onun güzelliğini yok eden özellikler olarak olumsuzlanır. Metinde kadına yönelik yer alan telkinlerin ana kurgusu güzelliğin ancak faziletle, takdire değer vasıflarla süslenirse anlam kazanacağ1 üzerinedir. Kadında güzelliğin tabiattan gelmediği durumlarda ise onun bıraktığ1 eksiklikler yine aynı fazilet ve vasıflarla giderilir. Metinde kadının yaratılış amacı ise okuyucuya şu şekilde sunulur: Hayatımı̨̧ tath tath paylaşarak zevkleri incelten, insanlğgn kederlerini hafifletmek için yaratılmıs olan kadin... (Steele, 1944: 317).

Kadında olması özendirilen ya da ona yakıştırılan diğer özellikler masumluk, dindarlık, iyi huyluluk, dürüstlük gibi niteliklerdir. İlgili satırlarda kadın için bu özelliklerin aynı zamanda ona yumuşaklık kazandıracağı, güzelliğini artıracağı vurgulanır. Metinde huy ve ruh güzelliğine, Âdem ve Havva'nın yaratılış öyküsü üzerinden görünürlük kazandırılmıştır. Okuyucunun algısını mistikleştirerek onun içsel dünyasında da konuya ilişkin bir meşruiyet bulmasını sağlayabilecek satırlar şu şekilde yer alır:

Milton cennette Havva'yı tasvir ederek Adem'i tanıtıp illk yaratılişta Havva’yı gördüğü zaman neler duyduğunu Adem'in ağzından meleğe söyletirken, kadını bir Yunan Venüs'ü şeklinde, sırf vücut ve yüz güzelliği bakımından değil, kendisine cazibe kudreti veren zekâsının parlaklığı bakımından tarif eder.

Her adımda zarafet, gözlerinde tanrısal bir şey vardı,

Her hareketinde vekar, her hareketinde sevgi (Steele, 1944: 321). bilgi verir:

Çevirmen yaptığı çevirilerin sonunda her iki yazar ve onların amaçları hakkında şu şekilde

The Spectator İngiltere'de Restorasyon devrinin sonlarına doğru; 1711 yllı başlarında neşrolunmaya başlanan gündelik bir gazetenin adıdır... Bu devirde Restorasyon'un sebebolduğu kargaşalık ve ahlâk düşkünlüğü yavaş yavaş ortadan kalkmaya, cemiyet daha düzenli hale gelmeye başlamıştı. Artık kadınlar da, orta tabakaya mensup kimseler de cemiyet hayatında bir dereceye kadar rol oyanayabiliyorlardı. Bununla beraber eski devirlerden kalma kötü geleneklerden, âdetlerden hücum etmișler, cemiyetin bozuk taraflarının 1slahı için savaşmışlardır. Bu arada birçok denemelerinde Fransız tesiriyle İngiltere'ye yayılan süs, moda iptilâsını da şiddetle tenkid etmişlerdir. Birincisi Addison'dan, ötekini de Steele'den aldığımız yukarıdaki iki parçada o zamanların kadınlarında görülen zaıflar belirtilmekte, bunları düzeltmek çareleri gösterilmektedir (Tercüme, 1944: 321). 


\subsection{Kadın Davranışları ve Mizacı Hakkında}

Derginin 3.cildinin 14.sayısında, Lessing'e ait Comeille'in Rodogune'ü ismiyle çevirisi verilen yazısında, Corneille'nin eserleri ağır bir üslupla eleştirilir (Lessing, 1942:100-105). Bu eleştirilerin çıkış noktası, Corneille'nin Rodogune isimli trajedisinde Kleopatra'nın hayatını ele alış biçimidir. Metnin ana teması Fransız yazar, Corneille'nin ve eserinin eleştirisidir ancak metnin satır aralarına inildiğinde alt temalardan birinin kadınların mizacına ilişkin olarak çizilen resim olduğu hemen fark edilir. Lessing, yazısında bir kadından beklenilmesi gereken davranış kodlarını ve kadına ilişkin mizacı, okuyucu için şu satırlarda genelleştirir:

... Hiç olmazsa şunu diyebiliriz: bir kadının, sadece kıskançlık duygusu ile, parçalamak için kocasına saldırması gibi evlatlarına saldırması da olmayacak şey değildir. Üstüne ortak getirildiğini, bundan böyle kocasının sevgisini de, kendi yüksek mevkiini de onunla paylaşacağını düşünmek, duygu, gurur nedir bilen bir kadını, artık yalnız kendinin olmayacak bir şeyi büsbütün feda etmek kararına pekâlâ sürükleyebilir...(Lessing 1942: 101).

Alıntıda geçen satırlarda, gururlu ve duygunun ne olduğunu bilen bir kadının kocasının başka bir kadını kendi üzerine eş edinmesini kabul etmeyeceği dile getirilir. Yukarıda geçen ifadelerde kadının kıskançlık dürtüsü ile eşini ya da oğlunu ödürebileceğinin vurgulanması, okuyucunun zihninde, kadın mizacına ilişkin olarak olumsuz çağrışımlara neden olabilecek bir etkiyi barındırmaktadır. Lessing'in kadın algısına ilişkin yazdığı diğer satırlarda ise kadında olması gereken mizacı şu şekilde aktarmıştır:

... bir kadının kibri erkeğinkinden de daha az tabiîdir. Tabiat kadını vurup öldürsün diye değil, sevsin diye yaratmıştır; kadın insanın içinde korku değil, şefkat uyandırmalıdır; bütün kudretini güzelliğinden, sevimliliğinden almalıdır; ancak okşıyarak hükmünü sürmeli, kaldırabileceğinden çok bir kudrete göz dikmemelidir. Kudreti kudrettir diye seven, her şeyi yükseklik hırsına bağlıyan, emretmekten, zulmetmekten, bütün bir milletin boynunu ezmekten başka saadet bilmiyen bir kadın: böyle bir kadın tarihte belki bir kere, hattâ birkaç kere gelmiştir ama gene de her zaman görülen bir şey değildir...(Lessing, 1942: 103).

İgili satırlarda kadınlarda kibir duygusunun erkeğe göre daha az olduğu, kadınların öldürmek için değil sevmek için var oldukları ve bir erkeğin içinde korku değil şefkat duygusunu uyandırması gerektiği, kadınların güçlerini güzelliklerinden ve sevimliliklerinden alabileceği bu nedenle de kadınların iktidar elde etmeye yönelik davranışlarının atipik olarak değerlendirileceğine dair sıralanan ifadeler, okuyucu açısından dönemin kadın profiline ilişkin yönlendirici çağrışımları doğaya ilişkin tezlerle destekleyen bir bağlamı barındırmaktadır.

Tercüme dergisinin 6. cildinin 31-32. sayısında modernitenin eleştirildiği Fénelon'a ait Eskilerle Yenilere Dair yazıda, lüks ve menfur âdetler üzerinden modern dünyanın eleştirisi yapılırken mevzu aynı zamanda kadm üzerinden de değerlendirilmiştir (Fénelon, 1945: 16-18). Fénelon'un, Homeros'un eserinde geçen bir kadın karakter ile bugünün kadınını karşılaştırdığı aşağıdaki paragrafta modern dönem Avrupa'sındaki kadınlarının karıştıkları entrikalar ve zamanlarını harcadıkları oyunlar utanç verici olarak aktarılmıştır: ... Nausikaa'nın vaktini geçirdiği mesgguliyetler

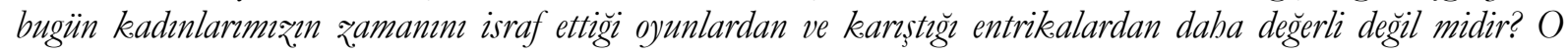
oyun ve entrikalar ki babalarmı bunlar şüphesizyüz kızartıc sayacaklardı... (Fénelon 1945: 18).

\subsection{Köylü Kadın ile Modern Kadının Karşılaştırılması}

Tercüme dergisinde yer alan çeviri metinlerde şehirli ve köylü kadının kıyaslandığ1 ve toplumsal değerler üzerinden kadınlarda olması gereken niteliklere ilişkin telkin edilen özelliklere göz gezdirilecek olursa, ortaya çıkarılan ifadeler bütününde, köylü/kasabalı kadının şehirli kadın karşısında yüceltildiği görülmektedir. Bu tür bir karşılaştırma, Erken Cumhuriyet döneminin köylü ve kentli kadın ayrımda da kendini gösterdiği için metinlere geçmeden önce döneme ilişkin söz 
konusu ayrıma değinmek, çevirilerin satır aralarında görünürlük kazanan anlamların, Erken Cumhuriyet Dönemi modernleşme sürecinde belirginlik gösteren söylemsel oluşumlarla ne dereceye kadar örtüştüğünü tespit edebilmek açısından önemlidir.

Kadın konusu daha önce de bahsedildiği üzere Türkiye'nin modernleşme sürecinde medeniyet kavramı ile birlikte ele alınmış ve Cumhuriyet'in ilanından sonra da medeniyet değişiminin temel bileşeni olarak gösterilmek istenmiştir. Kadınların kamusal görünürlüğü ve karş1 cinslerin toplumsal olarak kaynaşmasına yönelik gerçekleştirilen reformlar (örtünün terkedilmesi, 1924), kızlar ve erkekler için zorunlu temel eğitimin sağlanması (1924), kadınlara seçme ve seçilme hakkı gibi medeni hakların sağlanması (1934), şer'i hukukun kaldırılması ve Medeni Kanun'un kabul edilmesi (1926) kadınların kentsel yaşamın ve kamunun bir parçası haline gelmesini garanti altına almak için başvurulmuş önlemlerdir. Türkiye Cumhuriyeti'nin bu yeni medenileşmiş kadınının dış görünümü de, idealize edilen Avrupa medeni insan imajına göre ayarlanmak istenmiş ve kadın seçkinler tarafindan takip edilen moda, yeni bir medeniyet, yeni bir yaşam tarzı ve davranış biçimlerinin yüceltilmesi anlamına gelmiştir. Avrupa modasına göre kendine bir rol benimsemeye çalışan Türk kadını, zaman zaman bu yeni dile uyum sağlamakta zorlansa da kadınların kentsel mekânlarda görülmeleri ve tecrit sınırını aşarak görünürlük kazanmaları, Cumhuriyet'in ilk yıllarındaki dönüşümün cereyanlarını oluşturmuştur (Göle, 1996: 67). Kemalizmin milliyetçilik kanadı ise bu dönüşüme karşı tepkili bir tutum sergileyerek Batıcillğın eleştirisi yapmış, medeniyetçilik ve milliyetçilik arasındaki gerilimin temel merkezini teşkil etmiştir. Alafranga medeniyet ile geleneksel halk arasındaki ikilem, medeniyete ve halka olan yakınlık bağlamında Cumhuriyet reformlarının başarısını belirlerken, Kemalizm, bu iki yaklaşım arasındaki sentezi Anadolu kadin imgesinde aramıştır. Bu süreçte Anadolu kadın modernleşme yönünde toplumsal dönüşümün hem milli bilinci olarak Cumhuriyet reformlarının aşırıya kaçabilecek yanlarını yozlaşmaktan kurtaracak hem de kadının Osmanlı Dönemi'nin taassubundan kurtulmasını sağlayacak ve böylelikle de medeniyet ve millet arasında bir köprü oluşumunu kolaylaştıracak bir harç olarak düşünülmüştür (Göle, 1996: 67). Çünkü Anadolu kadın söylemi, yani köylü kadın kimliği Batı'nın tehdidi altında Türk ulusunun kendi kimliğini ve özgürlüğünü yitirmesine karşı ayakta durabilmesini sağlayan kurucu öğelerinden biri olmuştur (Sancar, 2017: 314). $\mathrm{Bu}$ düşünce biçimi aynı zamanda Erken Cumhuriyet Dönemi modernleşme dönemi edebiyatında modern düşünceleri aşırllklardan arnderma çabası ile Türk romanına yansıtılmıştır. Bu bağlamda aşırılığa kaçmayacak kadın ahlakının yaratılması adına saf ve temiz, biyolojik ve kültürel üretkenliği ve koruyuculuğu anneliğinde somutlaşan Anadolu kadım tasviri bu aşırılıklardan arındırmanın baş aktörü yapılmak istenmiştir. Anadolucu düşüncenin öncüsü Remzi Oğuz Arık'ın Dönüm dergisinin 1934 tarihli sayısında yer alan Köylü Kadın makalesinde, köylü kadın hakiki otantik kadın olarak şehirli kadının karşısında gösterilip doğuran, büyütüp besleyen anne-eş imgesi ile yüceltilirken; şehirli kadın lüks düşkünü olarak ciddiye alınmamıştır. Erken modernleşmenin muhafazakâr kadın yazarlarından Samiha Ayverdi de İbrabim Efendi Konağı isimli romanında büyük kentlerdeki alafranga ve yozlaşmış kadını olumsuzlarken karşısına iffetli, saf ve çalışkan yerli kadın modeli olarak Anadolu köylü kadmmn idealize etmiş̦tir (Sancar, 2017: 150-151).

Medeniyet ile milli kültürü kadın üzerinden ortak bir paydada buluşturmak isteyenlerden bir diğer önemli isim de İsmail Hakkı Baltacıoğlu'dur. Yazılarında kadın konusu üzerinden öne sürdüğü yaklaşımların, Cumhuriyetçi modernleşmenin hem Batıcılar hem Türkçüler hem de muhafazakârlar tarafından benimsenmesini kolaylaştırdığı söylenebilir. Kadın bu süreçte gelenek ile modern sentez içerisinde kurgulanmış ve Batıcı modernlik bu sentezden dışlanmıştır Baltacıoğlu, diğer Cumhuriyetçi modernistler gibi şehirli kadının karşısında Anadolu kadınını yüceltmiş ve kadın inkılabını şebirli kadının inkılabı olarak görmüştür. Anadolu kadınını ise asıl kadın olarak yüceltmiştir (Özman, 2006: 190-194).

Tercüme dergisindeki çevirilerde köylü-kentli kadın bağlamında benzer bir ayrımın var olup olmadığına bakılacak olursa, derginin 3.cildinin 14.sayısında yer alan Diderot'un Eski Hırkama 
Dair isimli hikâyesinden bahsedilebilir (Diderot, 1942: 90-99). Hikâyede, köylü kadın ile şehirli kadın arasında yapılan karşılaştırmada köy yaşamı değerli kılınırken, modern hayat ve o hayat içerisindeki kadın ise acınacak bir durumda tasvir edilir. Modern kadın, dün ve bugünün değerlerini uyumsuzca bütünleştiren düzenin somutlaşmış bir nesnesi olarak şu şekilde tanımlanır:

Bir köylü kadına ne kadar baksam tiksinmem. Bașını örten o kaba bez parçası, yanakları üzerine darmadağın dökülmüș ve saçlar, vücudunu yan kapatıp yarı çılak bırakan o çaputlar, ancak dizlerine kadar inen dar, berbat fistan, o çamurlu, yalın ayaklar gözlerimi incitmez: bütün bunlar benim saygı ile andığım birtakım insanların halidir, benim acıdığım talihsiz bir sınıfın çektĭgi, kaçınamadığı mahrumiyetlerin sanki bir arada kendilerini göstermeleridir. Ama şu kötü kadın beni iğrendirir; geçtiği yerde bir lâvanta kokusu kalıyormuş, ben gene ondan kaçar, başımı çeviririm: İngiliz tentenesi ile süslenmişşsapkası, yırtık kollukları, kirli ipek çorapları, yıpranmış ayakkabıları bana bugünün fikaralığı ile dünün bolluk içindeki hayatını birleşmiş bir halde gösterir (Diderot 1942: 93).

Benzer bir tonla, köy/kasaba hayatında yaşamını sürdüren bir kadının şehirli bir kadına üstün tutulduğu çevirilerden bir diğeri, derginin 2.cildinin 8.sayısında yer alan, William Hazlitt'e ait Alemlerin Cebline Dair isimli eseridir (Hazlitt, 1941: 104-119). Hayatını köyde/kasabada geçirmiş bir kadın, insan karakterini analiz. edebilme, mizah anlayzşna sabip olabilme ve insana ve hayata dair bilgi birikimi gibi özelliklerle, hayatını șehirde geçirmiş; romanlarla ve kitaplarla tabsil yapmıș bir şehirli kadın karşısında yüceltilir. Bu karşılaştırmanın, aynı zamanda, insanın diğer insanlarla birlikte sosyalleşebildiği, hayatı tecrübeleriyle öğrendiği doğal bir yaşamı, modern şehir hayatında kitaplardan öğrenilen bir yaşamdan çok daha değerli kıldığı söylenebilir. Bu değerli kılmanın, kadınlar üzerinden aktarılması okuyucunun zihninde yaratılması hedeflenen kadın alg1s1 bağlamında, dönemin modernleşme projesinin ilericilik ve Batıcılık iddiasındaki şehirli kadın söylemine bir tezat oluşturacak içerik taşımaktadır:

Ömrünü kasabada geçirmiş yaşlıca bir kadın ekseriya insan karakterini iyi bilir; hem de bildiklerine nümune olarak kasabada son elli sene zarfinda olan biten, söylenen, dedi kodusu edilen şeylerden hoş fikralar bulmakta mâhirdir. Bu bakımdan kasabalı kadının mahareti devrinin en bilgiç kadınının ayni müddet zarfinda basılan bütün roman ve hicviyeleriyle âşinalıktan ibaret olan tahsili yoluyla elde edebileceği maharetten çok daha üstündür. Gerçekten, şehirler halkının insan karakteri bilgisi esef edilecek derecede noksandır. İnsanları tam boy olarak değil, büst olarak görürler. Kasabalar halkı ise bir insanın başından gelip geçen her şeyi bilmekle kalmaz, ayni zamanda yüzünün çizgilerinin olduğu gibi, meziyet ve kötü huylarının irsiyetini bir kaç batın öteden çizebilirler; ve meselâ hareketlerindeki bir aykırıllğı bundan yarım asır evvel soyundaki bir kan karışıklığ1 sayesinde izah edebilirler... (Hazlitt 1941: 117).

$\mathrm{Bu}$ konu hakkında dergide yer alan bir başka çeviri, Rus yazar Aleksandr Puşkin'in kaleminden çıkan ve derginin 3. cildinin 14. sayısında Cingeneler ismiyle verilen hikâyesidir (Puşkin, 1942: 116-121). Metinde okuyucuya gönderilen alt iletilerden biri modern hayattaki kadınların bayağıllğı ve doğal yaşamdaki kadının şehir hayatındaki kadına olan üstünlüğüdür. Hikâyede geçen Aleko isimli karakter sevdiği kadın olan çingene Zemfira'nın doğal güzelliğini, şehirli kadınlarının yapay güzelliği karşısında şu şekilde yüceltir: Neymis şehirlerin şen gürültüsü̈? Așk olmiyan yerde neșe mi olur? Kadinlara gelince... Bak! senin arkanda pahah bir elbise yok, incilerin yok, gerdanliğn yok, gene de onlardan güzrelsin, olduğun gibi kal, benim canm sevgilim... (Puşkin, 1942: 117).

Bir kadının güzel olmasının maddi varlıklarla olamayacağı ve bir kadının doğal ve sade, yani olduğu gibi olmasıyla da bir erkeği kendine âşık edebileceği düşüncesi, okuyucunun zihninde, modern ve şehir hayatının pahalı elbiselerinin, ziynet eşyalarının değerini alçaltıcı bir bağlam oluşturabilecek çağrışımlar barındırır. 


\subsection{Modern Dünyada Toplumsal Normlar ve Kadının İsyanı: Kadının Ahlakındaki Sınır ve Cinselliğin Görünürlüğü}

Erken Cumhuriyet Dönemi'nde kadının toplumsal konumuna ilişkin olarak kurgulanan kadın kimliğine ait söylemler, kızların terbiyesi hakkında Parlamento görüşmelerinde dile getirilen ifadelerden takip edildiğinde kızların eğitiminin nihai hedefinin evlenmek, iyi ev kadın, iyi bir anne olmak ve millete çocuk yetiştirmek olarak belirlendiği görülür (Karaaslan-Şanl1, 2002: 286). Benzer şekilde dönemin Milli Eğitim şûralarında da kadın ailenin devamlılı̆̆1 için ev kadım olarak yetiştirilmek istenmiştir (Candeğer, 2017: 541). Cumhuriyet aydınlarının kadınların toplumsal alandaki varlıklarına dair ortak bir zeminde buluștukları temel nokta, kadınların kamusal alandaki varlıklarının cinselliklerinden arındırıldıkları ölçüde desteklenmesidir. Cumhuriyetin çağdaşlaşma projesinde kadınlar gerek anneler, eğitimciler, işçiler ve hatta gerekse savaşçlar olarak toplumsal hayata katılmaya teşvik edilirken kültürel anlamda ise kendilerinden bir takım kadın davranışlarına uymaları beklenene bireyler olarak tanımlanmışladır. Bu bağlamda kamusal yaşamda erkeklerle bir arada bulunan kadınların aynı zamanda bir o kadar da iffetli, erişilmez kadınlar olduklarını ispatlamaları beklenmiştir (Göle, 1996: 79).

Ahıska'nın eserinde incelediği radyo konuşmalarından yola çıkarak betimlediği Erken Cumhuriyet Dönemi kadın algısı, kendi duygularından vazgeçen, kadının bir arzu nesnesi olarak belirmediği, hatta yok olduğu, kadının kendine toplumda yüklenen görevler itibariyle kendi kişiselliğini, cinselliğini ve duygularını tamamen sildiği bir algıdır. Örneğin dönemin radyo konuşmalarında kadınların cinselliğine ve cinsel arzularına hiç değinilmemiştir(Ahıska, 2010:143). Kandiyoti, kadınların toplumsal yaşama ancak bu şekilde cinsiyetsizleştirilerek katılabilmesini onlara yeni bir peçe giydirilmesi olarak yorumlar (Kandiyoti, 2015: 161).

Aşağıda yer alan çevirilerde, Cumhuriyet Dönemi'nde kadınların toplumsal konumlarının farklı toplumsal ilişkiler bağlamında ihmal ve göz ardı edilen cinsiyet ilişkilerinin (Saktanber, 2015: 325) görünür kılınmasına yardımcı olabilecek ifadeler tespit edilmiştir. Bunun yanı sıra dönemin seçkinlerince kadın kimliğine atfedilen yeni davranış kalıplarına ve kadınların koyu renkli kostüm, kısa saç ve makyajsız yüzlerle kamu hayatında cinsiyetsizleştirilmelerine (Kandiyoti, 2015: 196) karşı okuyucunun zihninde aksi bir algıya neden olabilecek bağlamların yer aldığını söylemek mümkündür.

$\mathrm{Bu}$ çevirilerin tercih edilme sebebini anlamlandırma noktasında Türk solunun önemli isimlerinden Sabiha Zekeriya Sertel'in kadının özgürleştirilmesine dair düşüncelerine değinmek yerinde olacaktır. Sabiha Zekeriya Sertel'in düşüncesinde kadınların esaretinin nedeni erkekler değil toplumdur. Sertel, dönemin zihniyet kalıplarına uygun düşen bir kadın tiplemesinden yana olsa da ideal kadın tipini üretime katılan, toplumsal hayatta erkekle eşit olan ve ailede konumunu güçlendiren kadın olarak tahayyül eder. Diğer modernistler gibi o da aile konusuna odaklanır ve eski otoriter aile düzeninin krizde olduğunu ve yeni bir aile düzeninin geliştiğini dile getirir ancak aileyi kapitalist düzen gereği fuhuşun kurumlaşması olarak görür. Evlilik ve ailedeki eşitsiz konumlara odaklanır; Tek Parti Dönemi uluslaşma projesinden farklı olarak ailenin sürekliliği ve ölünceye kadar devam eden bir evliliği savunmaz. Ona göre aile her iki tarafin ortak anlaşmasıyla yaşayan bir kurumdur ve hiç kimsenin diğerini istemediği bir hayatı sonuna kadar yaşamaya mecbur etmeye hakkı yoktur. Bu nedenle evliliğin nikâhlı-nikâhsız ayrımına karşı çıkar, gayrimeşru çocuk tanımı eleştirir ve kadınların serbest münasebet hakkının kısıtlanması bağlamında bir özgürleşme sorunu olduğunu düşünür ve evlilik dışı ilişkilerden yana bir tavır alır. Öte yandan cinsel obje haline gelmiş burjuva kadınları da eleştirir. Ona göre Türk kadını sakin, haluk ve mütevazıdır ve ailesinin huzuru ve rahatı için çalışmayı da vazife bilir (Özman \& Bulut, 2003: 205211).

Sertelin kadına dair düşüncelerine paralellik arz eden çevirilerden biri Cingeneler'dir. $\mathrm{Bu}$ hikâyede kadın algısına ilişkin alt temalardan biri kadın üzerinden ahlak algısının kurgulanmasına 
ilişkindir. Aleko'nun sevdiği çingene kadın Zemfira, kedini deliler gibi seven kocası Aleko'dan bir süre sonra sıkılmış ve başka birine gönlünü kaptırmıştır. Bu durum şehir hayatını temsil eden bir karakter olarak Aleko için son derece gurur kırıcı ve alçaltıcı iken şehir hayatı ve modern düzenin normlarında uzak çingeneler için ise oldukça doğaldır. Netice de sevgi zorunluluktan ve bağlardan hoșlanmaz ve aşk özgürdür. Kadınların duygusal hayatlarını sadece tek bir erkekle geçirmelerinin doğal düzene olan aykırılı̆̆ı Aleko'ya Zemfira'nın babası tarafindan öğ̈̈tlenir. Bu durum okuyucu için normalleştirici bir etki uyandırabilecek bir koşutluk üzerinden babanın ağzından şu şekilde aktarilır:

Avut kendini, dostum. Daha bir çocuk o ! ... Doğru değil böyle sıkılman. Sen içlene içlene, dert çekerek seviyorsun: kadın gönlünde sevda bir şakadır. Bak, şu yüksek gökte ay, bir bağa bağlanmadan dolaşıyor; geçerken her yeri aydınlatması bir... İstediği buluta dalar, ona zengin parıltılar bağıșlar, sonra bir bașkasına geçer... Orada da çok kalmaz ... Kim ona gökte bir yer gösterip de kal burada diyebilir? Bir tazenin gönlüne de artık değişmiyeceksin, hep bir kişiyi seveceksin denir mi? (Puşkin, 1942: 119-120).

Tercüme dergisinde kadının ahlakını ele alan diğer bir çeviri derginin 1.cildinin 5.sayısında yer alır. Katherine Mansfield'a ait bu hikâyede Bertha isimli genç ve zengin bir kadının hayatından bir kesit sunulur (Mansfield, 1941: 457-469). Ana temas1 evlilik üzerine olan bu eserde, evli bir kadının hayata dair ruhsal algısı ve ilişkilerinde yaşanan gel-gitli duygu bunalımları konu edilir. Bertha'nın diyaloglarındaki ironi onun kendi ruh hali ile başkalarına karşı takındığı ruh hali arasındaki karşıtlığı yansıtır. Sosyal hayatta evinin mutlu kadını olarak gözükürken kendi içinde ise büyük bir belirsizlik hali hâkimdir. Hikâye üç kişi arasında yaşanan sıra dışı bir aşkı betimler. Bertha, kocası Harry ve Pearl Fulton adındaki bir kadın arasında geçen aşk ilişkisinde, kişisel ve öznelerarası zaman ve mekân deneyimlerinin kesişiminde arzu ve benlik duygularının cinsiyetler arası farklılıkları tasvir edilir. Bertha modern dönemin bir kadın karakterini temsil eder ve hikâyenin geçtiği yerde modern bir şehir olan Londra'dır. Bertha'nın kocası ise bu modern dünyanın zengin iş adamlarından biridir. Ancak Bertha'nın bu modern hayat içerisindeki toplumsal gerçeklik algısı kendi içinden gelenlerle uyuşmamaktadır:

Bertha Young otuzuna girmişti ama gene de böyle anlanı olurdu-yürüyeceğine koșmak istediği; kaldırımdan bir aşağı bir yukarı raksederek gitmek, çember çevirmek, bir şeyi havaya firlatıp tekrar atmak yahut ta hareketsiz gülmek- ama neye?-hiçbir şeye, hiçbir şeye, sadece gülmek-istediği anlar..Bunu ifade edebilmenin bir yolu yok mu? "Serhoşça ve nizama mugayır, harekette bulunmadan ifade etmenin bir çaresi yok mu? Medeniyet ne saçma şey! İnsana sanki niçin bir vücut verilmiş? Onu müstesna, pek müstesna bir keman gibi hep muhafazasında tutmak zorunda kalacak olduktan sonra, insana sanki neden bir vücut verilmiş?... (Mansfield, 1941: 457).

Bertha bu cümlelerden anlaşldığı üzere modern dünyanın bir kadın olarak kendinden beklediği bir takım normlar ve kısıtlamalardan ötürü içinde bulunduğu toplumsal alanı sorgulayan ve kendini hoşnutsuz hisseden bir ruh halindedir. Bir kadının içinden gelerek dans etmesinin, toplumsal normların uygun görmediği bazı coşkunluk hali belirten saçma davranışlarda bulunmasının ancak sarboș ve dürene aykıı kişilere özgü olabileceğinin sezdirilmesi, bir kadın olarak Bertha üzerinde toplum içerisinde uyması gereken kuralların baskısını hissetmesine neden olarak medeniyeti sorgulamasına yol açar. Medeniyet saşma bir şeydir (Mansfield, 1941: 457). İçindeki bu duygusal coşkunun kocası tarafindan da tuhaf karşılanacağını düşündüğü için bu ruh halini ona da açıklayamaz. Bertha'nın medeniyetin kendisi üzerinde yarattı̆̆ baskı, kocası ile yaptığı bir telefon görüşmesinden sonra bu kez üçüncü ağızdan tarif edilir: Bertha telefonu yerine asarken medeniyetin budalahktan da beter bir şey olduğunu düş̈̈nüyordu (Mansfield, 1941: 460).

Evindeki düzeninin de aynı şekilde bu medeniyetin getirdiği kurallar çerçevesinde değerlendirildiğini okuyucuya hissettirmek için Bertha'nın yastıkları dağıtması konu edilir. $\mathrm{Bu}$ 
şekilde Bertha (modernitenin kendisi üzerinde oluşturduğu baskıyı hisseden kadını temsilen) bu düzene karşı gelmek için salonda dadı tarafından nizamlı bir şekilde yerleştirilen yastıkları alıp gelişigüzel bir şekilde fırlatır ve bu şekilde oda ona daha canlı gözükür. Bertha'nın bu davranışı onun modernliğin getirdiği düzene olan tepkisi bağlamında değerlendirilebilir: ... Mary'nin fevkalâde itina ile yerlestirdiğ yastıklar birer birer alhp tekrar kanapelerin ve sedirin üstüne gelişi güzel firlatt. Birden bire her sey bambaskea bir bal aldr. Oda bemen canlanivermisti (Mansfield, 1941: 460).

Hikâye süresince modernliği olumsuzlayan tek karakter Bertha değildir. Onun evine gelen Mrs. Norman'in evden ayrilırken sarf ettiği şu cümlelerinde modern hayatta bireylerin kendilerini ve işlerini zamana göre düzenlemelerinin onların köleleşmelerinin bir göstergesi olduğu vurgulanır:... Biz, saatin ve trenin kurbanlariyz... (Mansfield, 1941: 468).

Bertha'nın evi için alış veriş yapması, kocası ile bir kulübe üye olmaları, saygın orta-sınıfa ait evli bir kadın için kabul edilen ve beklenilen davranış kalıpları olarak aksettirilmektedir. Ancak Bertha kendini yine de bir yere hapsedilmiş hissetmekte ve hatta evde kendi çocuğu ile ilgilenen dadının bile onu kendi bebeğine nasıl davranması gerektiği hakkında kısıtlamasını da bu esaretin bir uzantısı olarak görmektedir: Ne mânasız, seydi bu! İnsanm ne diye çocuğu olsun, onu- müstesna, pek müstesna bir keman gibi mahfazasi içinde değil de-bașka bir kadmm kollarnnda tutacak olduktan sonra-ne diye insanın çocuğu olsun? (Mansfield, 1941: 459).

Hikâyenin devam eden kısmında ise Bertha'nın evine gelen kadın konuklardan birine dair hissettiği cinsel yakınlığın betimlenmesi, kadınların cinsel duygularına dair apayrı bir pencerenin varlığını sezdirir nitelikte olup; tek tipleştirmeye karşıt bir duruşun da sembolü olarak yorumlanabilir. Bu duygu yani bir kadının başka bir kadına hissettiği cinsel arzu, okuyucuya alev alev yanmak, atessini körü̈klemek, nadir görülen bir duygu, saadet hąnesi gibi sözcüklerin yardımıyla örtük bir biçimde aktarılmıştır:

Bertha, tavırlarında garabet bulduğu her güzel kadın gibi ona da meftun olmuştu...Bertha..Miss Fulton'un koluna girdi...Bu serin kolun temasında ne vardı ki Bertha'nın içinde yanan ve ne yapacağını bilmediği o sonsuz saadet ateşini birden körükliyip-körükliyip-alevlendirdi, alev alev yaktı?..Bertha ansızın bildi-birbirlerine en uzun, en mahrem bir bakışla bakmışlar da: "Sen de mi öyle?,, demişler gibi-katiyetle bildi ki şu anda kurşuni tabakta güzel kırmız çorbayı karıştıran Miss Fulton da tam kendi duyduğunu duymaktadır... "Zannederim bu duygu kadınlar arasında pek, pek nadir olur. Erkekler arasında ise hiç olmaz diye düşündü...Öylece ne kadar zaman kaldılar? Her ikisi de, bu dünyaya ait olmıyan o 1şı çevresinde hapsedilmiş gibi idiler. Birbirlerini mükemmel surette anliyordular. Gögüslerinde yanan ve ellerinden, saçlarından gümüş çiçekler halinde dökülen bu saadet hazinesini bu âlemde ne yapacaklarını bilmiyerek, başka bir âlemin mahlukları gibi, ne kadar zaman öylece kaldılar? (Mansfield 1941: 460466).

Ancak yazar, kadınlar arasındaki bu duygusal yakınlığın uzun bir tasvirinden sonra hikâyesini çok daha çarpıcı bir son ile bitirir. Bertha, böyle bir deneyimden sonra ilk defa kocasını cinsel olarak arzu ettiğini düşündüğü bir zamanda Miss Fulton ve Bertha'nın kocası Harry'nin gizlice birbirlerine olan arzularını dile getirip bir buluşma ayarladıklarına şahit olur. Hikâye Bertha'nın her iki cins tarafindan da aldatıldığını fark etmesiyle son bulur.

Tercüme dergisinde yer verilen bu çeviri hikâyede temel olarak üç ana bileşenden söz edilebilir. Birinci bileşen ana karakter olarak bir kadının seçilmiş olmasıdır. İkinci bileşen, bu kadının, zengin ve rahat bir hayat içerisinde mutlu olması gerekirken kendine yabancılaşmıs olması ve toplumsal normların onu baskı altına alarak ruhunun kapana kısıldığını hissettirmesidir. Son bileșen de bu kadının toplumsal olarak son derece aykırı kabul edilebilecek bir tutum olarak başka bir kadına karşı hissettiği duygusal yakınlığın ardından aynı anda kocasına ilk defa duyduğu cinsel arzudur. Fakat hikâyenin sonunda cinsel yakınlık hissettiği kadın, onu kocası ile aldatır. 
Cumhuriyet reformları ile birlikte kadının toplumsal yaşama kazandırılarak yüceltilmesi, beraberinde kadın kimliğine yönelik algıda bir takım bedellerin ödenmesini de gerektirmiştir. Kadına kentsel mekânda ya da kamusal alanda sağlanan özgürlüğ̈̈n bedelinin, onun dişiliğinin, cinselliğinin ve hatta bireyselliğinin bastırılması olduğu söylenebilir. Özgürlük ile kadının namusunun ters orantılı olarak değerlendirildiği bir toplumda, kadınların kamusal yaşamda görünür olmaya başlamaları aynı zamanda onların bir o kadar iffetli ve erişilmez olmalarını ve bu açıdan toplum için ahlaki tehdit oluşturmadıklarını ispatlamak zorunda kalmalarını gerektirmiştir (Göle, 1996: 79). Kadının bastırılan dişiliği ve bireyselliği ve bunun üzerine kurulu bir saygınlık algısının, yukarıdaki çevirilerde, zamanının çok ötesinde sunulan fikirlerle parçalandı̆̆ söylenebilir. Bu aykırılık dönemin bazı düşünürlerinde hayat bulan fikirlerle uyumluluk gösterse de Erken Cumhuriyet Dönemi Tek Parti iktidarının kadına sağladığ1 özgürlük alanının oldukça dışına taşan bir düzlemde yer alır. Bu nedenle de bu çevirilerin, kadın algısına ilişkin egemen söylemi parçalayan bir etki ile cinsler arası ilişkilerden başlayarak dönemin mevcut hiyerarşik ilişkilerini ters yüz eden bir noktada durduğunu söylemek mümkündür.

\subsection{Medeniyet Göstergesi Olarak Kadın ve Komedi}

Türkiye'de ulusal düzeyde eğitim birliğini sağlayan 1924 Tevhid-i Tedrisat Kanunu, 1926 Medeni Kanun ve doğrudan kadın kilık kıyafetini hedef almasa da 1925'te çıkarılan Kılık Kıyafet Kanunu gibi düzenlemeler toplumsal hayatta dini esasların terk edilerek laik bir düzenin yerleştirilmesine zemin hazırlamış; kadın ve erkeği yasalar önünde eşit tutarak kadınların cemiyet hayatına katılabilmelerine olanak sağlamıştır. Bu nedenle de kadınların toplumsal ve kamusal alandaki kimliklerinde yer alacak değişimlerin, Erken Cumhuriyet Dönemi toplumsal değişimin temel dinamiklerinden bir tanesi olduğu söylenebilir. Ahıska, bu dönemde kadınların medeniyetin bir güvencesi ve aynı şekilde neşe kavramının da bir medeniyet göstergesi olduğunu, ulusun inşasında kadın ve neşenin bu nedenle bir tutkal vazifesi gördüğünü belirtir (Ahıska, 2005: 329). Tek Parti Dönemi’nde kadının toplumsal konumu Cumhuriyet reformları ile birlikte görünür hale gelmiş ve kadınlar Batılılaşma ve modernleşmenin temel yapı taşlarından biri olarak değerlendirilmiştir. Cumhuriyet'in ilk yıllarında yeni devletin modernliğini kadın imgeleri (geçit törenlerinde bayrak taşıyan şortlu, okul önlüklü ya da asker üniformalı genç kızlar ya da balo salonunda dans eden tuvaletli kadınlar) simgelemiştir (Deren, 2012: 389-390). Bu aynı zamanda kadının giyim kuşamında da değişikliğin görünür hale getirilmesi ve toplumsal imgelemde kadınlar üzerinde Batılı kıyafetlere meşruiyet kazandırılması demekti. Türkiye'de kadınların bu anlamda toplumsal ve kamusal alanda var olabilmeleri ve görünümleri ile de bu var oluşu tamamlayarak modern bir konuma kavuşabilmelerinin istendiği söylenebilir.

Tercüme dergisinde gerek neşe gerekse kadın konusunun medeniyetin göstergeleri olarak ele alınması noktasında derginin 1. cildinin 4. sayısında yer alan Komedi Mefbumu isimli çeviride, kadın-medeniyet-komedi arasında kurulan bağlantılar, dönemin medeniyet, kadın ve neşe algısı bağlamında egemen yaklaşımı destekler niteliktedir (Meredith, 1942: 354-357). Meredith, yazılarında evin koruyucu meleği olarak tasarımlanan kadın figürünün yerine toplum ile bütünleşmiş zeki, aktif ve kararlı kadın figürünü ön plana çıkarmaya çalışan yazarlardan biridir (Enrichetta Soccio, 2013: 355). İnsanlığın toplumsal evrimi ile ilgilenen bir yazar olarak, eserlerinde kurgusunu bu evrim üzerinden oluşturmuştur: materyalist, riyakâr ve egoist bir toplumdan iyiliğin, hakikatin ve adaletin hâkim olduğu bir toplum anlayışına doğru evrimleşen bir toplum. Meredith'e göre bu evrimsel sürecin gerçekleşmesinde erkekleri teşvik edecek iki mevhumdan bahsedilebilirdi: Kadmlar ve Komedi (Wolf, 1994: 68-81). Yazarın eserinden alıntı yapılarak çevirisi verilen bölümde, her iki kavramın farklı toplumların değişen ırksal özelliklerine göre ne ifade ettiğini ve medenileşme ekseninde milletler üzerindeki dönüştürücü etkisini takip edebilmek mümkündür. Çevirmenin özellikle çevirisini yaptığı bölümlere bakıldığında öne çıkan temaların, kadınlar ve ancak onlarla birlikte ortaya çıkabilecek olan komedi unsurunun toplumsal hayatın 
medenileşmesine olan katkısı olduğu söylenebilir. Çeviri metinde yer alan yargılardan biri de kadın ve erkeğin ayrı olarak varlıklarını sürdürdükleri toplumlarda cinsel açlığın artış göstereceğidir: ... Cinslerin ayru yașadiğz yerlerde, kadin ve erkek birbirlerine karşı, Portekiqlilerin dediği gibi, "affaimados, ac bir sekilde yetişiler (Meredith, 1942: 354).

Meredith, neşe ve kadın konusunda Doğu ve Batı toplumlarını bir ayrım gözetmeden karşılaştırmış; İspanya, Almanya, İtalya vb. ülkelerdeki komediyi belirleyen toplumsal unsurları ele almıştır. Bu ülkelerden özellikle Alman toplumu ve Doğu toplumlarının karakteristik özelliklerine değinilmiştir: ... Alman aile hayatında kadına verilen aşağı mevkiden dolayndır ki bu memleket hayatına aksetmis gülünc mubavereler mevcut değildir... Meredith, 1942: 355).

Benzer şekilde Araplardan örnek verirken dile getirdiği düşüncelerde ise hem komedi kavramına göndermede bulunmuş hem de kılık kıyafet bağlamında bir değerlendirme yaparak kadınların peçe kullanmalarının toplumsal hayatın bütünlüğü için engel teşkil ettiğini vurgulamıştır. İlgili satırlarda kadının her anlamda ikincil konumda olduğu toplumların hepsi barbar olarak nitelenmiştir: Binbir gece masallarmm da ispat ettiği gibi, şarka doğru gidilince, gülme ğe karşı fevkalâde hažr olan bu insanlar arasında, komedi namına biçbir şeyin mevcut olmadiğg görülür. Kadinın yüž̈u peçeli olduğu yerlerde cemiyet hayatı olamaz. Cemiyet hayat olmyyan yerlerde de bisler barbarca olur... (Meredith, 1942: 355).

Komedi kavramının dıșında çeviride, örtünmek ile kadınların kamu alanından uzaklaşması arasında kurulan ilişki, okuyucunun zihninde, örtünmenin negatif bir biçimde kodlamasına neden olacak bir anlamı ortaya çıkardığı için medeniyet-kadın-toplumsallaşma açısından oldukça önemli bir detaydir.

Çevirinin devam eden satırlarında, komedinin ancak medeni toplumlarda; medeniyetin de kadın erkek eşitliğinin esas alındığı, kadınların toplum içerisinde hürriyetlerinin sağlandığı adil ve eşit muamele gördükleri toplumlarda var olabileceğinin dile getirilmesi, okuyucunun zihninde, komedi ile kadın arasındaki ilisskinin medeniyet üzerinden dolaylı bir biçimde kurulmasını sağlamıştır. Aynı zamanda medeniyetin ölçüsü olarak da kadınların toplumsal ve kamusal konumunu gösterilmesi, özellikle tahsilli ve eğitimli kadın figürünün komediyi tetikleyici unsur olarak telkin edilmesi, Cumhuriyet Dönemi kadın algısına dair Batılı değişimin içselleştirilmesi bağlamında önemlidir:

... fakat komedinin mümkün olmadığı yerlerde hiçbir zaman medeniyet olamaz. Bu da cinsler arasında aşağı yukarı bir ictimaî müsavattan doğar....Maksadım tahsil ve terbiye görmüss kadınların komediyi ilham eden periyi en iyi dostlanından biri olarak telâkki etmeleri içindir...En salim görüşleriyle bir defa yabancı muhitlere ve etraflarına baksınlar; görecekler ki içtimaî serbestiye malik olmadıkları yerlerde komedi mevcut değildir...kadınların kendi kazandıkları veya âdil bir medeniyetin kendilerine bahşetmiş olduğu haklarda, gerek serbesti ve gerek imtiyazlar bakımından, erkeklerle müsavi olmağa doğru gittikleri yerlerde ve ancak böyle cemiyetlerde, hemen hayattan sahneye nakledilmeyi, roman veya șiir olarak teşmil edilmeyi bekliyen hakikî komedi inkişaf eder. Ve işte bu komedi, eğlencelerin en tatlısı, dostların en hoş sohbeti ve en makulüdür... (Meredith, 1942: 355-356).

Yukarıdaki satırlarda verilen bağlam içerisinde medeniyetin simgelerinden biri olarak kabul edilen gerçek komedinin doğabilmesinin önkoşulu; kadınların adaletli bir medeniyet sayesinde kendilerine verilen ya da kendi mücadeleleriyle kazandıkları bir takım haklar ve özgürlükler sayesinde toplumsal düzende erkeklere eşit bir statüye sahip olmaları şeklinde belirlenmiştir. Kadın ve erkek eşitliğinin olmadığı toplumlarda komediden bahsedilemeyeceği de vurgulanmıştır.

Çeviri metinde ele alınan medeniyet-kadın-neşe temalarının, Cumhuriyetin yeni referans kaynaklarının meşruiyet kazanmasına yönelik olarak, okuyucunun zihniyetini biçimlendirici içerikte olduğu söylenebilir. Cumhuriyetin yaratmak istediği kültürün ve birey tipinin 
formasyonunda da gerek neşe gerekse kadm medeniyetin iki önemli unsuru sayllarak yeni özne anlayışını besleyen kodlar şeklinde biçimlenmiştir. Yukarıda yer alan çeviride, komedi (neşe kültürü) ve kadın konularının medeniyetin iki simgesi olarak birbirini tamamlayacak şekilde gösterilmesi, çeviri metnin dönemin egemen söylemi ile örtüştüğünü göstermektedir.

\subsection{Kendi Aklına Güvenen Kadın}

Modernleşme çabalarının bir ayağını toplumdaki cinsiyet rollerinin yeniden tanımlanması oluşturur. $\mathrm{Bu}$ süreçte kadınlık ve erkeklik kalıplarının yeniden üretilmesi de gündeme gelir (Berktay, 2012: 275). Meşrutiyet Dönemi'nden itibaren siyasal modernite iradesi ve bu çerçevede kadının biyolojik yeniden üretimin ötesinde değerler aktarımındaki rolünün keşfi, onu potansiyel bir siyasal özne durumuna dönüşmüștür. Cumhuriyet Dönemi’nde de bu yöndeki kurucu zihniyet sürekliliğini devam ettirmiştir. Kızların gelecekteki özel yaşamlarında yalnızca görev bilincine sahip değil ama aynı zamanda akıl ve bilgi ile aydınlanmış kadınlara dönüştürülmesi hedeflenmiştir (Üstel, 2004: 320). Böylelikle Osmanlı Dönemi'nde gerek aile, miras hukuku ve çok eşlilik gibi medeni hukuk uygulamaları yüzünden, gerekse örtünme ve haremlik selamlık gibi toplumsal ve kültürel uygulamalar yüzünden, kadın ve erkek arasında kadın aleyhine bozulan dengenin (Göral, 2015: 226) yeniden sağlanarak kadınlara toplumda saygın bir statü kazandırılmak istenmiştir.

Kadınların kendi aklı ile hareket ederek ve kendi duygularına güvenerek kendi kaderini belirleyebileceğine ilişkin böyle bir çevirinin varlığı, derginin 4. cildinin 22. sayısında tespit edilmiştir. Herondas'ın kalemine ait Arac Kadın adlı hikâyenin kahramanı Metrikhe, Misır'da olan sevgilisini on aydan beri beklemektedir. İhtiyar bir kadın olan Gyliss'in çöpçatanlık hevesiyle onu başkasıyla evlendirmek yönündeki çabalarına karşın Methrike kendi aklına ve duygularına güvenmiş ve ihtiyar kadının bu kışkırtmalarına kibar bir şekilde karışlık vererek onu rencide etmeden geri çevirmiştir (Herondas, 1943: 189-144). Kendi aklı ile özel hayatında kendi kararlarını verebilen bir kadın imajının konu edildiği böyle bir çeviri metnin Tercüme dergisindeki yeri de dönemin kadın kimliğine kazandırılmak istenen kadın karakter özellikleri üzerinden anlam kazanmış olur.

\subsection{Evlilik/Aile}

Erken Cumhuriyet Dönemi sonrasında kadınlara medeni ve siyasî haklar tanınarak toplumsal statülerinin dönüşümünde çok önemli reformlar gerçekleştirildiğine daha önce değinilmişti. Daha önce bahsedilen bu reformlar, toplumsal yaşamı dinî esaslara göre düzenleyen uygulamalara son vererek, laik bir toplumsal düzenin kurulmasına olanak tanımıştır. Böylece kadınlara da erkeklerle eşit eğitim hakkı sağlanmış; kadın ve erkeği yasa önünde evlilik, boşanma, velayet, veraset gibi konularda eşit saymış ve kadınların dinî örtünme kurallarını aşıp kamusal yaşama katılabilmelerine olanak tanımıştır (Saktanber, 2015: 323).

Tek Parti Dönemi’nde kadınların toplumsal statüsünü dönüştürmek üzere kabul edilen kanunlar arasında, Türk Medenî Kanunu, toplumsal hayatın İslâm şeriatına göre düzenlenmesine son veren en önemli girişimlerden biri olmuştur. Bu yasayla gelen değişiklikler arasında evlilik kurumunun hukuki koruma altına alınması, çok eşliliğin yasaklanması ve kadına eş seçiminde, boşanmada, çocuklarının velayetinde ve mirasta eşit haklar tanınması gibi birtakım düzenlemeler yer alır. Ancak aynı yasa evin reisi olarak kocayı kabul etmiş, anlaşmazlık halinde çocukların velayetini babaya vermiş, kadının dışarıda çalışmasını kocanın iznine bağlamış ve ailenin temsil hakkını birincil derecede kocaya vermiştir. Bu şekilde evlilik içi ilişkilerde erkek egemenliğini muhafaza etmiştir. Bununla birlikle Medenî Kanun ve benzeri reformlarla İslam ataerkiliyeti ortadan kaldırllırken aile içi ilişkilerde erkeğin egemenliğinin ve cinsiyete dayalı işbölümünün İslâmî ataerkil değerlerle çelişmediği; tersine büyük ölçüde örtüş̧üğü görülür. Bu nedenle de Cumhuriyet'in kuruluş döneminde dinsel öğretiyle beslenen yaygın toplumsal cinsiyet değerlerine karşı çıkılmamış olduğu söylenebilir (Saktanber, 2015: 94). Bunun bir nedeni Yeşim Arat'ın 
belirttiği üzere kadınların geleneksel alanlarının düzenlenmesinde Batılı anlayış ile Türk toplumundaki geleneksel anlayışın karşıtlık içermemiş olmasıdır. Dolayısıyla kadınlar, kamusal alanda olduğu gibi geleneksel alanda da aile içi ilişkilere önem verecek bir biçimde davranmaları gerektiği düşüncesiyle geleneksel rolleri yerine getirmeleri konusunda özendirilmişlerdir (Arat, 1997: 100).

Söz konusu bu geleneksel rollerin dergi içerisinde yer alan çeviri metinlerde var olup olmadığına bakılacak olursa, derginin 5. cildinin 29.-30. sayısında Ksenophon'un Oikonomikos (Ev İdaresi Hakkında) isimli yazısında benzer bir rol tanımlamasının yer aldığ1 görülebilir (Ksenophon, 1945: 482-486). Bu eserin aynı zamanda antik-Yunan edebiyatından seçilmesi, geleneksel rollerin benimsetilmesinde antik Yunan değerlerini benimseyerek yükselen Batı'nın örnek alındığının bir göstergesi şeklindeki yoruma da açıtır. Oikonomikos (Ev İdaresi Hakkında), Apomnemoneumata isimli esere ek olarak yazılmış bir bölümdür. Bu eserde evlilik kurumu, salt üremek için gerekli bir kurum olarak değil, çizilen eğitimli yeni kadın portresi çerçevesinde, kadının üretime erkekle eşit şekilde katıldığı sosyal bir dayanışma, işbirliği olarak görülür. Evliliği eşler arasında kurulan bir ortaklık olarak resmeden yazar, bu ortaklığ1 Oikos'un mal varlığı, çocuklar ve kar1-koca (cinsiyet farklarından kaynaklanan) rolleri olmak üzere üç farklı açıdan ele alarak iyi bir evlilikte olması gerekenler hakkında bilgi verir. Metinde yer alan ifadeler, kadını, aile hayatında ev içinde yapılması gereken ev işlerini yapan, kocasının getirdiği malları muhafaza eden, yemek yapan, çocuklara bakmakla yükümlü olan taraf olarak betimler. Erkek ise vücut ve ruh olarak daha dayanıklı olduğu için yaratılışı gereği dışarıdaki işlere daha uygun cins olarak tanımlanır. Tanrı, kadına yavrularm erkeğin sevdiğinden daba çok sevmeyi babşetmiştir (Ksenophon, 1945: 484), aynı zamanda ... eve getirilen șeyleri mubafaza ile varifelendirdiği için, tann, korkak bir tabiatm mubafaza işine daha çok. uygun olduğunu bildiğinden kadina erkeğinkinden daha fazla bir korku payn vermişstir. (Ksenophon, 1945: 484) Tipk1 Ali Kami’nin 1927-1928 tarihli Yurt Bilgisi’nde tasvir edilen evdeki hayatın, aile bireylerini hiyerarşik ilişkiler bütünü içinde örgütlerken kadın ve erkeğe çizdiği rollerdeki gibi: Ev işleriyle çocuklarm bakımylla kadm uğraşır, erkek işe gider. Akş̧am eve dönünce her seyi önünde hažr bulur, erkek eğer hali vakti yerindeyse bir biżmetçi bulur ya da büyü̈kler, akrabalar yardım eder (Üstel 2004: 187). Erken Cumhuriyet Dönemi'nde ailenin temelinde keskin bir özel alan-kamusal alan ayrımına dayalı cinsiyetçi işbölümü vardır. Bu bağlamda erkek kazancı temin etmekle yükümlü ve evin reisidir, buna karşın evin ikinci reisi de annedir (Üstel, 2004: 188). Dolayısıyla tekrar çeviri metne dönülecek olursa Ksenophon'un çizdiği kadın portresinin, okuyucunun zihninde, dönemin kadının aile içindeki rolü ve imajına yönelik belirlediği kadın algısı ile örtüşecek biçimde içselleştirilmesini sağlayacak bir çerçeve sunduğu söylenebilir.

\subsection{Doğal Kadın: Çekici Kadın}

Erken dönem modernleşme sürecinde, Cumhuriyet kadının rol ve davranış kalıplarının yanında fiziksel görünümünün de geleneksel Türk kadını görünümünü terk etmesini gerektirecek şekilde belirlenmek istendiği söylenebilir. Bunun için geleneksel güzellik anlayışının yerine Batılı tarzda bir güzellik anlayışından yana bir tutumun benimsenmesine yönelik bir tavır sergilenmiştir ancak Batı tarzı bir güzellik tarzının benimsenmesi, kadını daha çekici daha bakımlı olması yönünde bir teşvik içermez. Bu güzellik anlayışında kadınların ait oldukları toplumun güzelliğini yansıtacak görünüm, hal ve davranışları benimsemesi beklenir. Bu beklentinin somut ifadelerini Sertel'in yazısında bulmak mümkündür: yalnı çehre veya göz güzelliği bir kadm güzel yapmaya kâfi değildir. Güzellik bir kültür ve bütün bir cemiyetin ve muayyen bir zamann güzellik telakekisini ifade etmektedir. (Şimşir 2007: 136). Benzer şekilde Yakup Kadri Süse Düşkün Bir Kadın, Genç bir Valideye, Carşafa ve Peçeye Dair gibi yazılarında kadınların fazla süslenmesine karşı çıkar. Güzellik kavramı, kadınların modernleşmesi gündemine bu şekilde taşınması, Erken Cumhuriyet Dönemi içerisinde kadınların moda ve güzellik konularına ilişkin ilgisini olumsuzlayan bir alg1 oluşturulmak istenmesiyle ilgilidir. Böylece belki de kamusal alanda görünür olan kadının cinsiyetsizleştirilmesi daha kolay 
olacaktı tıpk1 F. Rıfk1 Atay'ın şu sözlerinde telkin edilmek istendiği gibi: Bu genç kız ne boya güzeli, ne de yememek ve içmemekle vücudunu zaynflatan veya zaynf tutan moda güzelidir... (Şimşir, 2007: 108).

Tercüme dergisinde kadında doğal güzelliği yücelten çevirilerin tespit edilmiş olması, bu çevirilerin, Göle'nin bahsettiği alafranga medeniyet (Göle, 1996: 68) ile geleneksel Türk kadını arasında bir denge sağlanmasına yönelik olarak onu daha çok halka yaklaştırmak amacı ile tercih edilmiş olma ihtimalini kuvvetlendirir. Bu çeviriler arasında derginin 2.cildinin 12.sayısında yer alan Sextus Propertius'un Üç̧̧ïrinden bahsetmek yerinde olur (Propertius, 1942: 463). Bir kadina duyulan aşkın anlatıldığı çeviride, paraya bağlı süslenme biçimleri (krem, koku, bakım) doğaya ve aşka aykırı olarak nitelendirilmiş ve kadında doğal güzelliğin çekiciliği, tabiattaki güzelliklerle kurulan analojiler üzerinden tasvir edilmiştir. Çeviri metinde vurgulanan bu fikirlerle, okuyucunun zihninde, modern dünyanın iktisadi değerleriyle biçimlenen tüketim alışkanlıklarının çizdiği alafranga tüketen süs bebeği (Göle, 1996: 56) bir kadın profili yerine, doğal olanın yüceltildiği ve Erken Cumhuriyet Dönemi'nde oluşturulmak istenen süsten uzak, sadeliğini koruyan muhafazakâr bir kadın algısının desteklendiği söylenebilir.

Benzer biçimde daha önce bahsi geçen Rus yazar Aleksandr Puşkin’in Çingeneler isimli hikâyesinde, kadının doğal güzelliği şehirli kadınların yapay güzelliği karşısında şu şekilde yüceltilmiştir: Neymis şebirlerin şen gürültüsü? Aşk olmyyan yerde neşe mi olur? Kadmlara gelince... Bak!! senin arkanda pahal bir elbise yok, incilerin yok, gerdanliğn yok, gene de onlardan güzelsin, olduğun gibi kal, benim canim sevgilim... (Puşkin, 1942: 117).

\section{Sonuç}

Bu çalışmada Tercüme dergisinin yapısökümsel bir okuması ile Erken Cumhuriyet Dönemi kadın kimliğine ilişkin görünürlük kazanan söylemsel unsurlar belirlenmeye çalışlmış ve çeviriler üzerinden toplumsal öznenin kendini tanımlayacağ1 aydınlanma, hümanizma, akıl, bilim, evrensellik, ilerleme, üretim, kadın-erkek eşitliği gibi yeni kavramların ötesinde metinlerdeki ifadelerin bazen bu kavramların karşıtlarını ürettiği gözlemlenmiştir. Buna göre Tercüme dergisindeki kadın temalı çevirilerde üretilen söylemlerin, kadının kentli/köylü, Doğulu/Batılı, doğal/medeni, özgür/tutsak, iffetli/iffetsiz gibi zıtlıklar çerçevesinde tanımlandığ1 söylemek mümkündür. $\mathrm{Bu}$ zıtlıklar bağlamında çeviri metinlerin satır aralarında geçen ifadelerde toplumda kadına yönelik algının dönüşümünü tetikleyici ya da Batılı olmayı özendirici bir kaygıdan çok bazı şeylerin değişmezliğinin ya da devamlılı̆̆n sağlanmasına yardımcı motiflerle geleneği koruyucu bir tavırdan bahsedilebilir. Bu noktada seçilen metin tercihlerinin kadınların geleneksel rollerinin devamlılığını korumak noktasında muhafazakâr bir tavrı güçlendirmeye yönelik olduğunu gösterecek ifadelerin tespit edilmesi dikkat çekicidir. Örneğin Richars Steele ya da Joseph Addision gibi yazarlardan yapilan çevirilerle ailesine bağh olmak, sade bir bayat sürmek, kibar olmak ve köy hayatmm sakinliğini içinde barndırmak gibi daha pasif bir izlenim uyandıran özellikler, kadını daha çekici kılması ile özdeşleştirilerek, okuyucunun zihninde olumlanmıştır. Modern bir hayat tarzı ile aile hayatına bağlı olmayan, ev kadınlığından uzak, kendi aile hayatı dışında farklı toplumsal çevre ve ortamlarda bulunan kadın tipi olumsuzlanmıştır. Çevirilerin satır aralarında makyaj, boyanma, piyasadaki sabte güzellik malz̧emeleri ve kaçak güzellik ilâçlan gibi yöntemler piyasa araçları olarak adlandırılmış ve güzelliğin maddi varlıklarla olamayacağı düşüncesi vurgulanarak kadınlarda dış güzellikten ziyade iç güzelliğin, doğallığın ve sadeliğin önemi ön plana çıkarılmıştır. Güzelliğin ancak faziletle, takdire değer niteliklerle süslendiğinde anlam kazanacağını vurgulayan; masumluk, dindarlık, iyi huyluluk, dürüstlük gibi sıfatların kadınlara güzellik katacağını dile getiren ifadelerin, kadınların toplumsal rol ve konumlarının tanımlanması bağlamında iktidarın söylemini yeniden ürettiği söylenebilir. Kadınların bir erkeğin içinde korku değil şefkat duygusunu uyandırması gerektiğ̣i, kadın gücünün güzelliğinde ve sevimliliğinde saklı olduğu; bu nedenle de kadınların iktidar elde etmeye yönelik davranışlarının atipik olarak değerlendirileceğine dair sıralanan Lessing'e ait ifadeler, okuyucu açısından dönemin kadın profiline ilişkin yönlendirici 
çağrışımlar içermektedir. Tercüme dergisinde yer alan çeviri metinlerde kadın algısına dair görünür kılınan bir başka özellik ise şehirli ve köylü kadının kıyaslamasında ortaya çıkar. Bu kıyaslamanın yapıldığ1 metinlerde ortaya çıkarılan ifadeler bütününde, köylü/kasabalı kadının şehirli kadın karşısında yüceltildiği görülmektedir. Bunun için Diderot'un modern hayattaki kadını acınacak durumda tasvir ettiğ ancak buna karșlık köylü bir kadını bir köylü kadina ne kadar baksam tiksinmem diye yücelttiği satırların ait olduğu metnin tercih edilmiş olması ya da William Hazlitt’in kasabah kadinin mahareti devrinin en bilgic kadinmm ayni müddet zarfinda basılan bütün roman ve bicviyeleriyle âşinalıktan ibaret olan tabsili yoluyla elde edebileceği maharetten çok daha üstündür dediği metnin çevirisine yer verilmesi tesadüf olamayacak kadar benzer anlamları içermektedir. Metinlerde köylü kadın ile şehirli kadın arasında yapılan karşılaştırmalarda köy yaşamı değerli kılınırken, modern hayat ve o hayat içerisindeki kadın ise acınacak bir durumda tasvir edilmiş; modern kadın, dün ve bugünün değerlerini uyumsuzca bütünleştiren düzenin somutlaşmış bir nesnesi olarak ele alınmıştır. Köylü/doğal kadının, şehirli/modern kadınların bayağılı̆̆1 karşısındaki üstünlüğü, hem Cumhuriyet reformlarının aşırıya kaçabilecek yanlarını yozlaşmaktan kurtarmak hem de medeniyet ve millet arasında bir köprü oluşumunu sağlamak üzere köylü kadın kimliğini yüceltmeye dönük söylemleri destekler nitelikte bir bağlamda verilmiştir. Erken Cumhuriyet Dönemi'nde ailenin temelinde keskin bir özel alan-kamusal alan ayrımına dayalı cinsiyetçi işbölümünün olduğuna daha önce değinilmişti. Kadınların toplumsal statüsünü dönüştürmek üzere kabul edilen kanunlar, evlilik kurumunu hukuki koruma altına alınıp, çok eşliliğin yasaklanması ve kadına eş seçiminde, boşanmada, çocuklarının velayetinde ve mirasta eşit haklar tanınması gibi bir takım düzenlemelerle kadını medeni haklarla donatmıştır. Ancak bu düzenlemelerin aile içi ilişkilerde erkeğin egemenliğini ve cinsiyete dayalı işbölümü koruması bakımından kadının geleneksel rolünü devam ettirmesi yönünde erkek egemenliğini muhafaza ettiğini söylemek mümkündür. Dergide söz konusu bu geleneksel rollerin devamını sağlayacak ifadelere rastlanmıştır. Örneğin Ksenophon'un Apomnemoneumata adlı eserinden alıntılanarak Ev İdaresi Hakkemda adılla çevirisi verilen bölümde kadın, aile hayatında ev içinde yapılması gereken ev işlerini yapan, kocasının getirdiği malları muhafaza eden, yemek yapan, çocuklara bakmakla yükümlü olan taraf olarak betimlenirken, erkek ise vücut ve ruh olarak daha dayanıklı olduğu için yaratılışı gereği dışarıdaki işlere daha uygun cins olarak tanımlanmıştır. Dergide kadın algısına ilişkin olarak satır aralarında göze çarpan bir başka ifade bütünlügü medeniyet-kadın-neşe arasında kurulan ilişki üzerinedir. Cumhuriyet'in yaratmak istediği kültürün ve birey tipinin formasyonunda gerek neşe gerekse kadın kavramlarının medeniyetin iki önemli unsuru sayılarak yeni özne anlayışını besleyen kodlar şeklinde görünür kılındığına daha önce de değinilmişti. Dergide de benzer bir ilişkinin yer aldığ1 satırlara rastlanmıştır. Komedinin ancak medeni toplumlarda; medeniyetin de kadın erkek eşitliğinin esas alındığı, kadınların toplum içerisinde hürriyetlerinin sağlandığı adil ve eşit muamele gördükleri toplumlarda var olabileceğinin vurgulandığı bu satırlarda, kadın ve komedi medeniyetin iki simgesi olarak birbirini tamamlayacak şekilde ele alınmıştır. Buna göre kadın-medeniyetkomedi arasında kurulan bağlantıların, dönemin medeniyet, kadın ve neşe algısı bağlamında benimsenen egemen yaklaşımı desteklediği söylenebilir.

Erken Cumhuriyet Dönemi’nde kadına yönelik olarak gerçekleştirilen reformlar neticesinde kadınlara sağlanan bazı özgürlüklerin bedelinin, onun dişiliğinin, cinselliğinin ve hatta bireyselliğinin bastırılması olduğuna daha önce değinilmişti. Kadının bastırılan dişiliği ve bireyselliği ve bunun üzerine kurulu bir saygınlık algısının, dergide yer alan bazı çevirilerde, zamanının çok ötesinde sunulan fikirlerle parçalandığı söylenebilir. Bu aykırılık dönemin bazı düşünürlerinde hayat bulan fikirlerle uyumluluk gösterse de Erken Cumhuriyet Dönemi Tek Parti iktidarının kadına sağladığı özgürlük alanının oldukça dışına taşan bir düzlemde yer alır. Bu nedenle de bu çevirilerin, kadın algısına ilişkin egemen söylemi parçalayan bir etki ile cinsler arası ilişkilerden başlayarak dönemin mevcut hiyerarşik ilişkilerini ters yüz eden bir noktada durduğunu 
söylemek mümkündür. Bu konu hakkında yapılacak daha detaylı çalışmalar, derginin söyleminde ortaya çıkarılacak kırılmalar açısından önemlidir.

Toparlamak gerekirse, Tercüme dergisinde kadına ilişkin söylemi belirleyen çevirilerin kadınların geleneksel rollerinin devamlılı̆̆ını korumak noktasında muhafazakâr bir tavrı güçlendirmeye yönelik olduğunu gösterecek ifadeler içerdiğini söylemek mümkündür. Bu noktada derginin, Erken Cumhuriyet Dönemi'nde modern Türk kadını ve onun değerlerini düzenleme, pekiştirme ve taşıma nesnesi olarak hâkim projeler ile örtük bir politikayı takip ettiği ve böylece seçilen metinlerin tercihlerinde siyasal iktidarın yeniden üretildiği bir alan olarak değerlendirilebileceği söylenebilir. Dönemin seçkinlerinin söylemlerinde kadınların tanımlanış biçimleriyle çeviri metinlerde görünürlük kazanan kadın algısı arasındaki paralellik, kadınların toplumsal rollerinin tanımlanma biçimlerinin sürekliliğini göstermesi bağlamında milliyetçi bir perspektifi desteklemektedir. Dergide çevirisine yer verilen bazı metinlerin, kadınlara ilişkin çelişkili bir algının yaratılmasına neden olabilecek unsurları içermesi, Erken Cumhuriyet seçkinlerinin kadına ilişkin karmaşık ve çelişkili düşünce dünyalarının bir yansıması olarak değerlendirilebilir. Bu bağlamda çeviri için tercih edilen metinlerin ya da metinlerden verilen kesitlerin, derginin kendi mantığ1 içinde açıklayamadığı ya da anlamlandırmada güçlük yaşadığ1 noktalarda, erken dönem modernleşme sürecindeki kadın algıları ve kadınlara dair reform projelerine bakmak çevirilerin anlamsal dizgesini sağlayan bir resim ortaya çıkarılmasında yardımcı olmuştur. Genel bütünlügün kesintiye uğradığı bu noktalar üzerinden yapılacak ileriki çalısmalar farklı bakış açılarının inşa edilmesini olanaklı kılabilir.

\section{Kaynakça}

ADAK, Hülya (2011). “Otobiyografik Benliğin Çok Karakterliliği: Halide Edip’in İlk Romanlarında Toplumsal Cinsiyet”, Kadinlar Dile Düşünce, der. Sibel Irzık\& Jale Parla, ss.161-178, İstanbul: İletişim Yayınları.

AHISKA, Meltem (2005). Radyonun Sibirli Kapısı, İstanbul:Metis Yayınları.

AHSKA, Meltem (2010). Occidentalism in Turkey: Questions of Modernity and National Identity in Turkish Radio Broadcasting, London: Tauris Academic Studies.

ALEXANDRA, Assis Rosa (2010). "Descriptive Translation Studies (DTS)", Handbook of Translation Studies, Volume 1, ed. Yves Gambier, Luc van Doorslaer, pp. 94-104, Amsterdam \& Philadelphia: John Benjamins Publishing.

ANDERSON, Benedict (1991). Imagined Communities: Reflections on the Origin and Spread of Nationalism, London \& NewYork: Verso

ARAT, Yeşim (1997). "The Project of Modernity and Women in Turkey," Rethinking of Modernity and National Identity in Turkey, der. Sibel Bozdoğan, Reşat Kasaba, pp. 95-112, Seattle \& London: University of Washington Press.

ARI, Sevinç (2014). Çeviri Sosyolojisi, İstanbul: Aylak Adam Kültür Sanat Yayıncillk

BERKTAY, Fatmagül (2012). "Doğu ile Batı’nın Birleştiği Yer: Kadın İmgesinin Kurgulanışı”, Modern Türkiye'de Siyasi Düsünce: Batıcllke, ed. Tanıl Bora, Murat Gültekingil, ss.275285, İstanbul: İletişim Yayınevi.

CANDEĞER, Ümmügülsüm (2017). Türk Milli Eğitim Şûra Kararlarnda Kadınn Yeri (1939-2014), Türkiye Cumhuriyeti'nin Ekonomik ve Sosyal Tarihi Uluslararası Sempozyumu Cilt:1, yay.haz.Erdem Ünlen, ss.523-548, Ankara: Atatürk Araştırma Merkezi Yayınları.

DAVIS, Kathleen (2001). Deconstruction and Translation, Manchester: St. Jerome Publishing. 
DEREN, Seçil (2012). “Kültürel Batılllaşma”, Modern Türkiye'de Siyasi Düsünce: Modernleșme ve Batıllassma, ed. Tanıl Bora, Murat Gültekingil, ss. 382-402, İstanbul: İletişim Yayınevi. Press.

DERRIDA, Jacques (1981).Dissemination, çev. Barbara Johnson, London: The Athlone

DERRIDA, Jacques (1985). "Letter to a Japanese Friend", Derrida and Differance, ed.David Wood\&Robert Bernasconi, ss.1-5, Warwic: Parousia.

EROĞLU, Osman (2012). 'Yapısökücülük ve Necip Fazıl'ın 'Beklenen' Şiirine Bir Uygulama Denemesi”, Turkish Studies, 7(1): 1095-1098.

EVEN-ZOHAR, Itamar (2002). "The Making of Culture Reperoire and the Role of Transfer", Translations: (Re) Shaping of Literature and Culture, der. Saliha Paker, ss.166-174, İstanbul: Boğaziçi Üniversitesi Yayınları.

EVEN-ZOHAR, Itamar (2008). "Culture Planning, Cohesion and the Making and Maintenance of Entities", Beyond Descriptive Translation Studies: Investigations in Homage to Gideon Toury, ed. Anthony Pym, Miriam Shlesinger, Daniel Simeoni, pp. 277-292, Amsterdam \& Philedelphia: John Benjamins Publication Company.

GENTZLER, Edwin (2001). Contemporary Translation Theories, UK: Multilingual Matters.

GÖLE, Nilüfer (1996). The Forbidden Modern: Civilization and Veiling, USA: The University of Michigan Press.

GÖRAL Özgür Sevgi (2015), “Afet İnan” Modern Türkiye'de Siyasi Düsünce: Kemalizm, ed. Tanıl Bora, Murat Gültekingil, ss.220-227, İstanbul: İletişim Yayınevi.

HOBSBAWM, Eric \& Terence RANGER (2000). The Invention of Tradition, Cambridge: Cambridge University Press.

KANDIYOTİ, Deniz (2015). Cariyeler, Bacılar, Yurttaşlar, İstanbul: Metis Yayınları.

KARAASLAN-ȘANLI, Halise (2012). Hasan Âli Yücel Konusmaları, Ulusal Kimlik İnșası ve Politik Retorik, Ankara: Ankara Üniversitesi Yayınevi.

LUCY, Niall (2004), A Derrida Dictionary, USA: Blackwell Publishing.

MAYER, Tamar (2000). "Gender Ironies of Nationalism: Setting the Stage", Gender Irones of Nationalism: Sexing the Nation, der. Tamar Mayer, pp. 1-24, London \& New York: Routledge,

MORAN, Berna (2011), Edebiyat Kuramlar ve Elesstiri, İstanbul: İletişim Yayınları.

ÖZMAN Aylin ve Ayça Bulut (2003), "Sabiha Sertel: Kemalizm, Marksizm ve Kadın Meselesi”, Toplum ve Bilim, 96: 205-211.

ÖZMAN Aylin (2006), "İsmail Hakkı Baltacıoğlu'nu Yeniden Okumak: 'Cinsi Latifin Ölümü ya da Erkekliğe Methiye", Toplum ve Bilim, 107: 190-194.

RANCHOD-NILSSON, Sita \& Mary Ann TÉTREAULT (2000). "Gender and Nationalism: Moving Beyond Fragmented Conversations", Woman, State and Nationalism: At Home in the Nation, der. Sita Ranchod-Nilsson ve Mary Ann Tétreault, pp.1-17, London \& New York: Routledge.

RASIŃSKI, Lotar (2011). "The Idea of Discourse in Poststructuralism: Derrida, Lacan and Foucault" Contemporary - Learning - Society, 1: 7-22.

SAKTANBER, Ayşe (2015). "Kemalist Kadın Hakları Söylemi”, Modern Türkiye'de Siyasal Düșünce: Kemaližn, ed. Tanıl Bora \& Murat Gültekingil, ss.323-333, İstanbul: İletişim Yayınları. 
SANCAR, Serpil (2017). Türk Modernleșmesinin Cinsiyeti, İstanbul: İletissim Yayınları. $159-171$

SAYDAM, Oktay (2009). "Yazında Dekonstrüksiyon Kavramı", Frankofoni, Ankara: 21:

SOCCIO, Anna Enrichetta (2013), "Against Orthodoxy: Sex, Marriage, and Gender Roles in George Meredith's Poems and Novels", Journal of Literature and Art Studies, 3(6): 355-362.

ŞİMŞİR, Esra (2007). Türk Modernleşmesinde Kadın Kimliğinin İnşası: Falih Rıfkı Atay, Mustafa Şekip Tunç, Zekeriya Sertel'in Çalışmaları Üzerine Karşılaştırmalı Bir İnceleme, (Yayınlanmamış Yüksek Lisans Tezi) Hacettepe Üniversitesi, Sosyal Bilimler Enstitüsü, Siyaset Bilimi ve Kamu Yönetimi Ana Bilim Dalı, Ankara.

TOURY, Gideon (2002). "Translation as a Means of Planning and Planning of Translation:A theoritical Framework and a Exemplary Case", der. Saliha Paker, Translations: (Re)Shaping of Literature and Culture, pp. 148-165, İstanbul: Boğaziçi Üniversitesi Yayınları.

TUNAYA, Tark Zafer (2016). Türkiye'nin Siyasi Hayatında Batıllaşma Hareketleri, İstanbul: İstanbul Bilgi Üniversitesi Yayınları.

ÜLKER, Çiğdem (2016), "II. Meşrutiyet Dönemi Fikir Akımlarında Kadın ve Evlilik Tartısmaları", Tarih Okulu Dergisi, 27: 33-56.

ÜSTEL, Füsun (2004). Makbul V atandașın Peșinde, İstanbul: İletișim Yayınları. Routledge.

VENUTI, Lawrence (2000). The Translation Studies Reader, London \& New York:

WOLF, Lynn E.(1994). "A Bracing Corrective: Woman and Comedy in Geroge Meredith's Case of General Ople and Lady Champer", Essays in Literature, Spring, 21(1): 68-81, Erişim tarihi: 03.05.2017, (https://www.questia.com/read/1G1-16082467/a-bracing-correctivewomen-and-comedy-in-george-meredith-s ).

WYKE, Ben van (2010), "Ethics and Translation", Handbook of Translation Studies, Volume 1, ed. Yves Gambier, Luc van Doorslaer, pp. 111-115, Amsterdam \& Philadelphia: John Benjamins Publishing.

\section{İncelenen Çeviri Metinler}

ADDISON, Joseph (1944). “Cleanthe'nin Hikayesi_The Spectator'den İki Deneme”, çev. Turgut S. Erem, Tercüme, 4(23): 308-313.

ALEKSANDR, Puşkin (1942). "Çingeneler”, çev. Vâlâ Karabuğa, Tercüme, 3(14): 116-121.

DIDEROT, Denis (1942). “Eski Hırkama Dair”, çev. Vahdi Hatay, Tercüme, 3(14): 90-99.

FÉNELON, François (1945). "Eskilerle Yenilere Dair", çev. Adile Ayda, Tercüme, 6(3132): 16-18.

HAZLITT, William (1941). "Âlimlerin Cehline Dair", çev. Ulviye Isvan, Tercüme, 2(8): 104-119.

HERONDAS, (1943). "Mimoslar-Aracı Kadın”, çev.Suat Sinanoğlu, Tercüme, 4 (22): 189194.

KSENOPHON (1945). "Oikonominos”, çev. Oliver Davies ve Müzehher Yeğinobalı, Tercüme, 5(29-30): 482-486.

LESSING, Gotthold Ephraim (1942). "Corneille'nin Rodogune'ü”, çev. Sabri Yalın, Tercüme, 3(14): 100-105. 
POLATEL, Ceyda (2020). “Tercüme Dergisinde Kadın Kimliğinin İnşası:

Bir Yapısöküm Denemesi”, Mavi Atlas, 8(2): 362-388

MANSFIELD, Kathrine (1941). "Saadet”, çev. Ulviye Isvan, Tercüme, 1(5): 457-469.

MEREDITH, George (1942). "Komedi Mevhumu", çev. Mebrure Aksel, Tercüme, 1(4): 354-357.

PROPERTIUS, Sextus (1942). “Üç Şiir”, çev. Lamia Kerman, Tercüme, 2(12): 462-469.

STEELE, Richard (1944). "Kadın Güzelliği_The Spectator'den İki Deneme”, çev. Turgut S. Erem, Tercüme, 4(23): 314-321. 